\title{
Knowledge Connectivity in an Adverse Context: Global Value Chains and Pakistani Offshore Service Providers
}

\author{
Noemi Sinkovics $^{1,2}$ (D) Umair Shafi Choksy ${ }^{3}$ - Rudolf R. Sinkovics ${ }^{1,2,4}$. \\ Ram Mudambi ${ }^{2}$ (D)
}

Received: 11 October 2016 / Revised: 25 November 2018 / Accepted: 28 November 2018 /

Published online: 11 February 2019

(c) The Author(s) 2019

\begin{abstract}
This paper contributes to theory building efforts around the concept of knowledge connectivity and its relevance in buyer-supplier relationships in global value chains. We use the Pakistani IT industry as our study context. Pakistan suffered a significant adverse perception bias following terror attacks in 2008-09. We based our illustration on the experiences of 12 Pakistani offshore service providers (OSPs) who succeeded in offsetting the negative implications of the country's adverse political environment. The case firms link into two distinct value chain configurations. In each configuration, we observe a distinct course of strategic action, which we term stepup and break-out, respectively. While these observations emerged from the Pakistani context, the implications of the resulting dynamic framework for theory and practice go beyond this particular adverse country setting.
\end{abstract}

Keywords Global value chains · Connectivity · Adverse context · Practices · Supplier strategies · Global sourcing · Economic geography · Comfort zone · Catch-up

\section{Introduction}

The present paper sets out to investigate how 12 Pakistani offshore service providers (OSPs) linking into two distinct value chain configurations survive and grow despite their adverse home country context. Adverse economies are characterised

Rudolf R. Sinkovics

Rudolf.Sinkovics@manchester.ac.uk

1 Alliance Manchester Business School, The University of Manchester, Manchester, UK

2 Department of Strategic Management, Fox School of Business, Temple University, Philadelphia, PA, USA

3 The University of Kent, Business School, Canterbury, UK

4 LUT University, Lappeenranta, Finland 
by frequent violent episodes, terrorism and other forms of conflict threatening individuals' physical security (Brück et al. 2011; Dai et al. 2013; Hiatt and Sine 2014; $\mathrm{Wu}$ and Chen 2014). Not only does Pakistan belong to the category of traditional emerging markets due to the low level of development of its factor markets and institutions (Bilgili et al. 2016; Hoskisson et al. 2013), but the uncertainty which stems from significant security threats additionally makes it an adverse environment. This heightened uncertainty and unpredictability creates fear and affects the way individuals and organisations make economic decisions and interact. For example, incumbent firms in such environments are expected to adopt a short-term focus and duplicative imitative learning strategies (Bilgili et al. 2016). As a consequence, the constraints imposed on incumbent firms by their adverse environment are far greater than those in mid-range or newly industrialised economies (Bilgili et al. 2016).

Jensen and Petersen (2013) emphasise the importance of management's comfort zone with respect to the nature of global sourcing decisions. They suggest that managers' risk perception, risk tolerance and ability to employ risk-reducing measures greatly influence their comfort zone. As a consequence, it can be expected that management will be less comfortable with entering sourcing relationships with suppliers from adverse economies than with those from mid-range emerging or newly industrialised economies. Industry data seem to support these propositions. In the wake of deadly terror attacks in Pakistan in 2008-2009, exports and foreign direct investment (FDI) inflows decreased significantly (Hussain 2011; Lopez-Calix and Touqeer 2013; Yousaf and Li 2015). Yet, the market bounced back from this shock. This raises the question of how Pakistani OSPs managed to address the constraints imposed by their adverse home country context. More specifically, what did they do to change the risk perceptions of their foreign clients?

To answer these research questions, we draw on concepts and frameworks from economic geography and global value chain (GVC) analysis. The importance of widening the analytical focus from 'location' to other aspects of space is increasingly being recognised in international business research (cf. Beugelsdijk and Mudambi 2013; Cook et al. 2018). Space here is understood as a multidimensional concept that, in addition to geographical distance, also includes structural, cognitive and relational aspects (Cano-Kollmann et al. 2016; Tornroos et al. 2017). By following Cano-Kollmann et al. (2016), we argue that understanding the nature and evolution of the connections between OSPs and their foreign clients will help answer our research questions. The central concept here is connectivity, that can be defined as the communication and interaction mechanisms and relational structures that support the back-and-forth flow of knowledge and ideas between two or more organisations (Cano-Kollmann et al. 2016). This is important, because the knowledge- and technology-intensive nature of the OSPs' service requires a higher level of connectivity than lower-skill, labour-intensive offerings that usually characterise traditional emerging economies (cf. Bilgili et al. 2016). As a consequence, in order to link into the value chains of their clients, the OSPs in our study had to first initiate and then gradually build and maintain connectivity. This was especially challenging due to the clients' negative risk perceptions about Pakistan, making the development of sophisticated boundary spanning capabilities extremely important (Schotter et al. 2017).

The structure of the paper is as follows. The next section offers a brief historical account of the Pakistani software industry to introduce the study context. 
Subsequently, the conceptual background section introduces the theoretical background to our analytical framework, and this is followed by the methods section. The findings part of the paper comprises two parts: First, we demonstrate how the Pakistani software industry fits into the offshore services GVC and how the local institutional setting shapes the conditions for and constraints on connectivity. The third part of the findings section presents the processes and actions OSPs used to bypass and/or alleviate those constraints.

\section{A Brief History of Pakistan's Software Industry}

Before the 1980s, software service outsourcing was limited to large domestic firms in developed countries. In the 1990s, the need for cost reduction became more pressing, leading to greater demand for low-wage service labour to work in globally standardised IT services in developing countries (Currie and Seltsikas 2001; Lee et al. 2014). These events coincided with the liberalisation process in Pakistan (Lodhi 2011b; Zaidi 2015). From the 1990s onwards, a number of liberal policies were introduced in the country, including the elimination of import restrictions and the creation of public and private associations. However, local conditions, particularly the political environment, did not support the early evolution of the industry (Bokhari 2000). Political instability, economic recession, and international sanctions were major inhibitors of growth. Efforts to promote the software industry in international markets through the Pakistan Software House Association (PASHA) and the Pakistan Software Export Board (PSEB) brought limited success. This was mostly due to weak institutional support that failed to adequately foster trust or improve the quality of either education or the ease of gaining access to financing. By early 2000, Pakistan's software exports remained at $\$ 30 \mathrm{~m}$ in comparison to the $\$ 3.9 \mathrm{bn}$ of neighbouring India (Christophe 2015; Hassan 2000; Khan 2014).

In 2001, the challenges for Pakistan were further exacerbated after the 9/11 terrorist attacks. There was a general distrust towards Pakistan in the US. This stifled the inflow of foreign investment. Pakistan became a 'no go' zone for a number of countries (Zaidi 2015). The increasingly negative perception of Pakistan in the world led to the relocation of many software projects to other countries (Carroll 2002; Kessler 2001), and software exports had plummeted to $\$ 16 \mathrm{~m}-\$ 18 \mathrm{~m}$ by the end of 2001 (Jamal 2003; Khan 2001). However, once the country became a frontline supporter of the 'War on Terror' agenda, the US lifted its sanctions and provided support through a significant amount of financial aid (Ahmed 2011; Hussain 2011; Khan 2014). From 2002 onwards, the software industry became more vibrant again, a pattern accelerated by the increase in the demand for international outsourcing (Dalesio 2001), improving economic conditions in Pakistan (Lodhi 2011a) and increasing government support (Khozem 2001). From 2002 to 2006, the industry experienced a growth of $50 \%$ per annum. The software exports increased from $\$ 20 \mathrm{~m}$ during 2002-2003 (Jamal 2003) to \$72m during 2006-2007 (Khan and Lew 2018; SBP 2007).

In 2007, the political environment became hostile once again (Lodhi 2011a, b). Events such as the lawyers' movement, the state of emergency, the Lal-Masjid massacre, the assassination of politician Benazir Bhutto and deteriorating security 
conditions led to the eventual demise of General Musharraf's government (Christophe 2015; Zaidi 2015). Pakistan's support for the 'War on Terror', poor policies under Musharraf's government and political instability led to the rise of terrorism within the country. This became further evident under the new, democratically elected government of Pakistan's People Party (PPP) (Yusuf 2013). Between 2008 and 2009, the terrorist organisation Tehreek-e-Taliban launched deadly attacks throughout the country, resulting in the death of 3000 civilians (Christophe 2015; Yusuf 2013; Zaidi 2015). As the security conditions in Pakistan deteriorated, western countries imposed a travel ban, preventing their citizens from visiting the country. This led to decreases in both exports and inflows of FDI, as well as damage to the nation's reputation (Hussain 2011; Lopez-Calix and Touqeer 2013; Yousaf and Li 2015).

In the face of this deterioration in its business environment, the software industry could not maintain its pre-2007 growth. Software export growth slowed down significantly between 2007 and 2010. It declined from 50 to 40\% during 2007-2008 (\$101m), further to $20 \%$ during $2008-2009(\$ 121 \mathrm{~m})$, and to just $2.5 \%$ during $2009-2010$ (\$124m) (SBP 2007, 2008, 2009, 2010, 2011). The industry started to bounce back following this nadir, regaining a growth rate of 40-50\% per annum. Exports reached \$204m during 2011-2012 and \$458m during 2015-2016 according to State Bank of Pakistan calculations (Alfalah 2015; Khan 2011; Khan and Lew 2018).

\section{Conceptual Background}

In this section we provide an overview of the theoretical thinking that guided our analytical operationalisations. Jensen and Petersen (2013) provide a valuable integrative theoretical framework that offers important insights into management's strategic choice on the tactical versus strategic/transformational global sourcing continuum. Tactical sourcing decisions are mostly driven by cost-saving aspirations. They tend to manifest as arms-length relationships between the sourcing firm and its partners. Strategic/transformational sourcing, on the other hand, is primarily motivated by the sourcing firm's need for talented and innovative human capital. The emphasis is on value enhancement rather than cost reduction. However, this framework does not view tactical and transformational sourcing as dichotomous. Instead, it allows us to look at global sourcing as a combination of defining features that manifest as degrees on a continuum, where tactical and transformational sourcing represent opposite ideal types. The authors furthermore introduce the argument that managerial decision making is contingent on managers' comfort zone, which is in turn influenced by their risk perception, risk tolerance and the extent to which they can introduce measures to control the perceived risks (Jensen and Petersen 2013).

The focus on managers' comfort zone and how it changes over time offers important insights into how connectivity between two firms is built over time (Schotter and Beamish 2013). This concept is even more important in our context, where the OSPs are situated in an adverse environment. However, Jensen and Petersen's (2013) process model of transformational global sourcing does not consider, or does so only indirectly, a range of factors deriving from the host country's institutional environment, such as regulations and political stability. In fact, a high level of political risk 
is expected to discourage foreign clients from offshoring or offshore outsourcing services that require frequent interaction and have an innovative component (Doh et al. 2009). Jensen and Petersen's (2013) framework also does not include the strategies and actions of sourcing partners, directed at effectuating change in the interfirm relationship (cf. Choksy et al. 2017; Sinkovics et al. 2018).

To this end, we draw on two frameworks that complement the insights from Jensen and Petersen's (2013) process model. We utilise the GVC analysis framework to identify factors shaping initial macro- and meso-level parameters of the potential sourcing relationship (cf. Gereffi and Fernandez-Stark 2016). In other words, we rely on the GVC analysis framework to identify factors that initially influence the comfort zone of the clients. Furthermore, to capture how suppliers address the ensuing macro- and meso-level constraints on connectivity, we utilise a practicebased approach developed in the economic geography literature (cf. Jones and Murphy 2011). The latter is a micro-foundational framework designed to provide an understanding of how micro-level factors can shape or bypass meso- and macrolevel factors (cf. Felin et al. 2012; Foss 2009), and operate at the managerial level (Schotter and Beamish 2013). It was designed to address the limitations of the GVC governance framework, among other similarly static frameworks, so as to unpack the dynamics of economic change, livelihoods and governance (cf. Jones and Murphy 2011; Sinkovics et al. 2015). This is in line with the objectives of an emerging body of literature within the broader GVC literature, that focuses on firm-internal processes of disarticulation and counter-action (Ponte et al. 2018). In other words, the GVC analysis framework focuses on providing an intricate yet necessarily broad map of global industries by identifying the main actors, the relationships between said actors, and the activities relevant for a given global industry, along with the locations where these activities are performed. As a consequence of the breadth of such a mapping exercise, finer, micro-level details are necessarily sacrificed. The practice-based approach supplies these missing insights, along with a temporal dimension that allows the researcher to investigate the dynamics of inter-firm relationships over time (cf. Buckley et al. 2018; Sinkovics and Sinkovics 2018).

\subsection{A GVC Approach to Framing Connectivity}

The GVC analysis framework aims to gain an understanding of how global industries are organised, how they evolve and/or fail over time, and how individual countries or firms can enhance their positions within global industries, markets or even individual value chains (Lee and Gereffi 2015). The framework can be adjusted to different scales. This means that, depending on the researcher's interests, it can be used to map a global industry, one or more industries in a specific country, or a specific value chain stretching across country borders. This is a function of the framework's configuration, encompassing six analytical layers, namely, (1) the input-output structure of a global industry or a single value chain (what are the relevant activities?), (2) geographical scope (in which locations are the activities carried out?), (3) governance (how are the relationships between the industry actors such as lead firms and suppliers orchestrated?), (4) upgrading (how do individual 
countries gain a better position within a global industry, or how do individual firms gain a better position within a specific value chain?), (5) local institutional contexts (how do different institutional contexts affect specific activities and/or the cross-border coordination of activities?) and (6) industry stakeholders (who are the relevant stakeholders and what is their sphere of influence?) (cf. Gereffi and FernandezStark 2016). As a consequence, the GVC analysis framework adopts a much broader focus than Jensen and Petersen's (2013) process model of transformational global sourcing.

Additionally, the governance dimension of the framework offers five ideal types regarding how lead firms might govern/control their suppliers. These are the market, modular, relational, captive and hierarchy types of governance (Gereffi et al. 2005). They can be regarded as five distinct degrees on the tactical-transformational continuum of global sourcing, ranging from arms-length relationships, subsumed under the market type of governance directed by price, to complete vertical integration represented by the hierarchical mode of governance. The differentiation between the ideal types is based on (1) the complexity of information and knowledge that is needed for a transaction, (2) the extent to which this information and knowledge is codifiable and (3) the capabilities of the suppliers.

Under a modular type of governance, highly competent suppliers take full responsibility for the production of goods based on codified and often digitized client specifications. This codification often manifests in the form of standards. In a captive type of relationship, suppliers that are less competent are dependent on and controlled by one or a few very powerful buyers. These buyers provide suppliers with detailed instructions. Lastly, in a relational type of governance buyers and suppliers with unique or not easily replicable capabilities are mutually interdependent and engage in frequent two-way communication in order to transmit complex knowledge and information that is difficult to codify. The regulation of the ensuing two-way dependence can be achieved "through reputation, social and spatial proximity, family and ethnic ties, and the like" (Gereffi et al. 2005, p. 86; Ponte et al. 2018).

Each ideal type embodies varying levels of control and coordination that MNE lead firms are predicted to exert over their value chain partners. The higher the complexity of the transactions and the lower the capabilities of the suppliers, the more actively lead firms are predicted to coordinate and control the value chains and the larger the power asymmetry between lead firms and their suppliers (Gereffi et al. 2005). Additionally, these predictions are expected to be moderated by managers' comfort zone (Jensen and Petersen 2013) as well as other strategic considerations (McDermott et al. 2013) such as assignment duration (Buckley et al. 2018). However, even without considering possible moderating effects, the different configurations of control and coordination predicted by the GVC governance framework and the ensuing level of power asymmetry can serve as indications of the extent to which inter-firm connectivity is necessary (Kawakami and Sturgeon 2011; Sturgeon 2009).

Additionally, the extent to which lead firms perceive geographical proximity as important varies across the five ideal types of governance (Ponte and Sturgeon 2014). Given the need to exchange tacit knowledge and sensitive information, the relational form of governance is most likely to embrace co-location and continuous two-way interaction. In contrast, the high level of dependence of captive suppliers 
on lead firms can be expected to ensure compliance without co-location or frequent face-to-face communication. Similarly, the considerable extent of codification and standardisation in the market and modular modes of governance creates a high tolerance of distance, and reduces the need for geographical proximity and continuous two-way interaction. In a hierarchical mode of governance, value chain actors are united under the management structure of the same firm (Ponte and Sturgeon 2014).

The degree of connectivity development is furthermore shaped by suppliers' local institutional context, the actual geographical distance between connecting firms, the dominance of industry stakeholders and their influence on inter-firm relationships, as well as by the nature of upgrading trajectories within specific industries (cf. Gereffi and Fernandez-Stark 2016). However, inter-firm relationships are not static. It is possible for value chain participants to make changes to connectivity parameters over time, through negotiations, contestations and/or trust building (cf. Allen 2003; Choksy et al. 2017; Kawakami and Sturgeon 2011). To understand how these changes happen, we need to turn our attention to micro-foundations (cf. Felin et al. 2012; Felin et al. 2015).

\subsection{A Practice-based Approach to Unpacking Connectivity}

A group of scholars within economic geography suggest the study of intra- and interfirm practices as a way to understand the dynamic nature of the relationships that ultimately shape the organisation, coordination and control of value chains (Jones and Murphy 2011). In other words, this approach goes beyond the mapping of static relationships and attempts to capture how and why they change over time. The concept of practice includes a wide range of actions from routinised to improvised or accidental (Jones and Murphy 2011). Similarly to the emerging body of literature in strategic management, practice research aims at building micro-foundations (e.g., Felin et al. 2015). We argue that a practice-based approach represents an effective way to study the development process and evolution of connectivity because it takes into account the interconnections between place, space and organisation (cf. CanoKollmann et al. 2016). In other words, by investigating the actions of OSPs from a social, temporal and spatial perspective, we can gain insights into how they have initiated and developed connectivity with their clients. The social perspective covers the relational aspects of inter-firm transactions. The spatial perspective looks into how organisations are bridging geographical, psychic and cultural distance, how location-specific factors shape each organisation's behaviour and expectations, and why certain actions are carried out at certain locations instead of others. The temporal perspective is aimed at understanding when and why specific actions are carried out (cf. Jones and Murphy 2010, 2011; Murphy 2003; Plank and Staritz 2015). These three aspects are interconnected and overlapping.

Jones and Murphy (2011) propose four dimensions for the study of practice, namely, perceptions, social performances, patterns and power relations. Similarly to micro-foundations research in strategic management, these dimensions span the 
overarching categories of individuals, processes and interactions, and structure (Felin et al. 2012).

The perceptions of individuals are important in this context, because they influence how they interpret situations, how they translate cues and symbols from one context to another, whether they recognise opportunities in their environment, and if so how they act upon them (cf. Jones and Murphy 2011; Murphy 2003). Perceptions are subjective and path dependent, and are also influenced by the individual's motivations, expectations, desires and short- and long-term objectives (Jones and Murphy 2011). This is in line with Jensen and Petersen's (2013) propositions about the impact of managers' comfort zone on their global sourcing decisions.

Social performance is a behavioural dimension. It can be broken down into social interactions and communications that ideally lead to mutually beneficial or at least acceptable relationships. Prerequisites include the actors' ability to recognise what constitutes situationally appropriate behaviour and language, as well as the ability to identify common or overlapping objectives-all of which can be summarized under the heading of effective boundary spanning (Schotter et al. 2017). With the advancement of digital technologies, social performance can also take place in virtual space, thus connecting distant agents (Jones and Murphy 2011). This may of course introduce an additional set of risks and challenges (cf. Pezderka and Sinkovics 2011; Yamin and Sinkovics 2006).

Patterns can be seen as regularised forms of behaviour guided by rules, norms, routines, conventions and materials. Because these guiding structures are anchored in formal and informal institutions, actors who are familiar with these institutions will expect to see the ensuing practical behaviour that is derived from these rules, norms, routines, etc. Such patterns tend to be of a longstanding nature, and thus relatively difficult to change (Jones and Murphy 2011).

Power is the fourth dimension of practice. This dimension significantly influences the relationship dynamics between actors - in our case between OSPs and their clients. This framework differentiates between structural and relational power. Structural power determines the opportunities available to specific actors. Relational power is embedded in interactions and is shaped by the individuals' strategies and/or tactics aimed at influencing the actions/responses of other individuals (Allen 2003; Jones and Murphy 2011). We acknowledge that there are more elaborate discussions on power in several bodies of literature (e.g., Hess 2008; Pfeffer and Salancik 1978). However, for the purposes of this specific study, reducing power dynamics to these two dimensions is sufficient.

\section{Methods}

\subsection{Research Design}

The current study adopts an exploratory, flexible-pattern-matching design with nested template analysis (King 2012; Sinkovics 2018; Sinkovics et al. 2014) to conduct a multi-level qualitative analysis of the factors influencing the initiation, development and maintenance of connectivity between the Pakistani OSPs and 
their foreign clients. A flexible-pattern-matching design encompasses elements of a deductive approach while at the same time allowing patterns to emerge inductively from the data. We derived an initial template (i.e. coding sheet) from the two analytical frameworks discussed in the previous two sections.

Table 1 provides an overview of the template, containing the individual theoretical patterns, the corresponding operationalisations and the expected observational patterns. The latter are comparable to preliminary propositions that form part of our initial theorising (Sinkovics 2018). The first column indicates the direction of each inferred relationship. This is an attempt to capture the dynamic interaction between macro-, meso- and micro-level factors. The second column indicates the underlying analytical framework, namely, either Gereffi and Fernandez-Stark's (2016) GVC analysis framework or Jones and Murphy's (2011) practice framework. The third column shows the specific dimensions we chose for the analysis, and the fourth the operationalisation of these dimensions. The fifth and sixth columns specify the anticipated observational patterns we expected to find in the empirical data.

In the analysis process, we matched these expected patterns with the actually observed empirical patterns. While full pattern matching is used in explanation building and theory testing, flexible pattern matching is most suitable for exploration and theory building (Sinkovics 2018). An additional difference between the two techniques arises from the level of inherent rigidity. The template/coding sheet developed for full pattern matching cannot be changed during the analysis. The aim is to test which of several predefined alternative explanations best explains the observed pattern. Flexible pattern matching, on the other hand, allows for the emergence of new, unexpected dimensions, as well as the revision of the hypothesised relationships. Our study falls into the latter category. The main purpose of this research design is to use the pattern matches or mismatches as an aid to theorising, and to identify potential 'breakdowns' in our understanding based on current frameworks and/or empirical findings (Alvesson and Kärreman 2007).

Our study covers the time period between 2007 and 2014. We chose 2007 as a starting point because it marked the beginning of the political crisis in Pakistan. The year 2014 marks when the data collection was completed. We used theoretical sampling to identify eight companies in two value chain configurations. Theoretical sampling is commonly used in exploratory studies in order to help identify, examine, fill out, and/or extend theoretical categories (Eisenhardt and Graebner 2007; Voss et al. 2002). The selection criteria included the OSPs' (1) level of success in Pakistan, (2) level of innovativeness and (3) age and size. As access to financial data on companies is limited in Pakistan, we identified successful OSPs from local newspapers, local industry-related platforms and award functions. Additionally, we collected information about potential case firms' service portfolios and products from their websites. Finally, to qualify for selection, OSPs set-up dates had to fall within 2007 or later so that we could capture the effects of the 2007 political crisis. Furthermore, we were interested in small and medium-sized firms with employee numbers in the range of 20-300. 


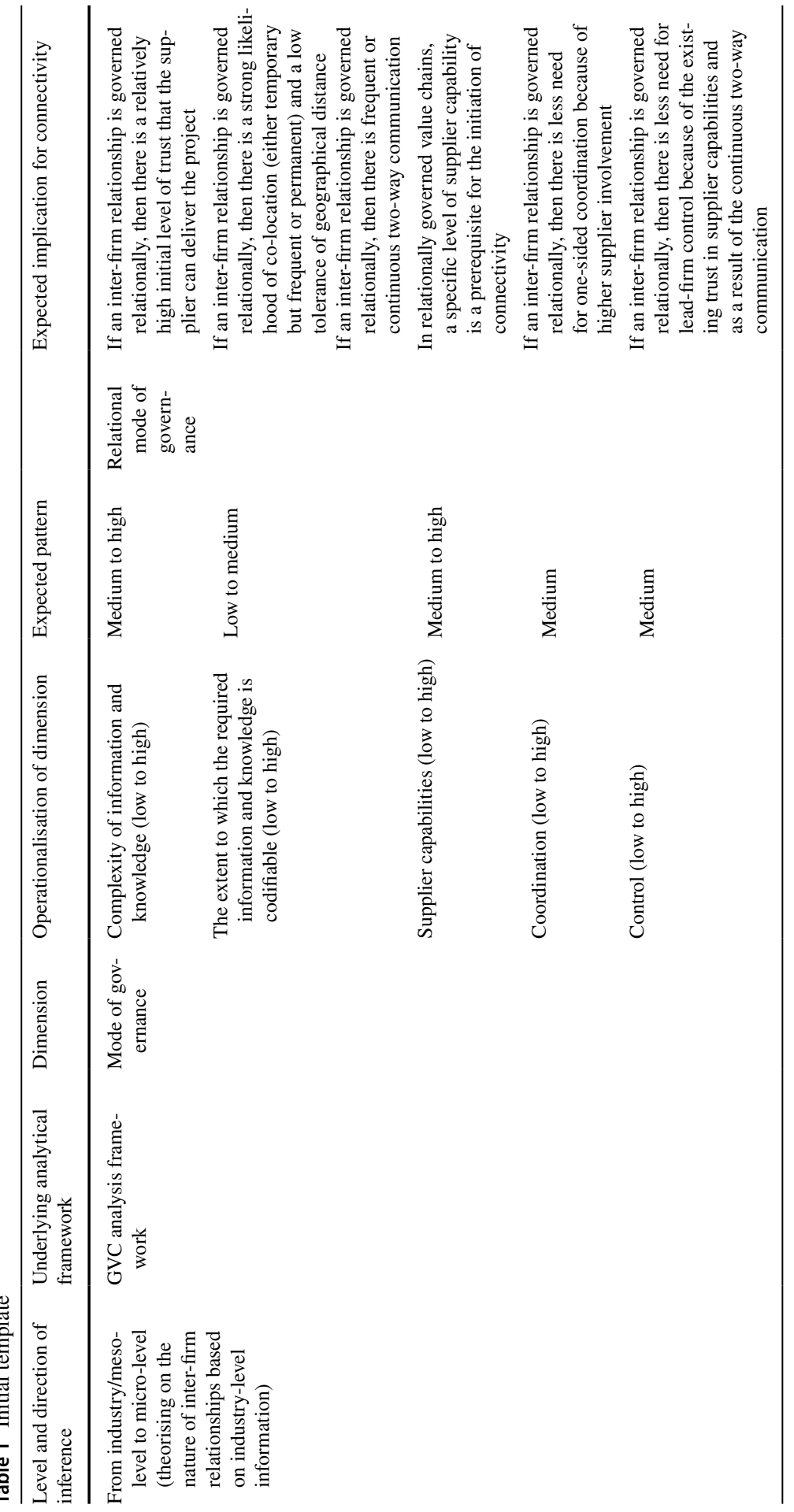




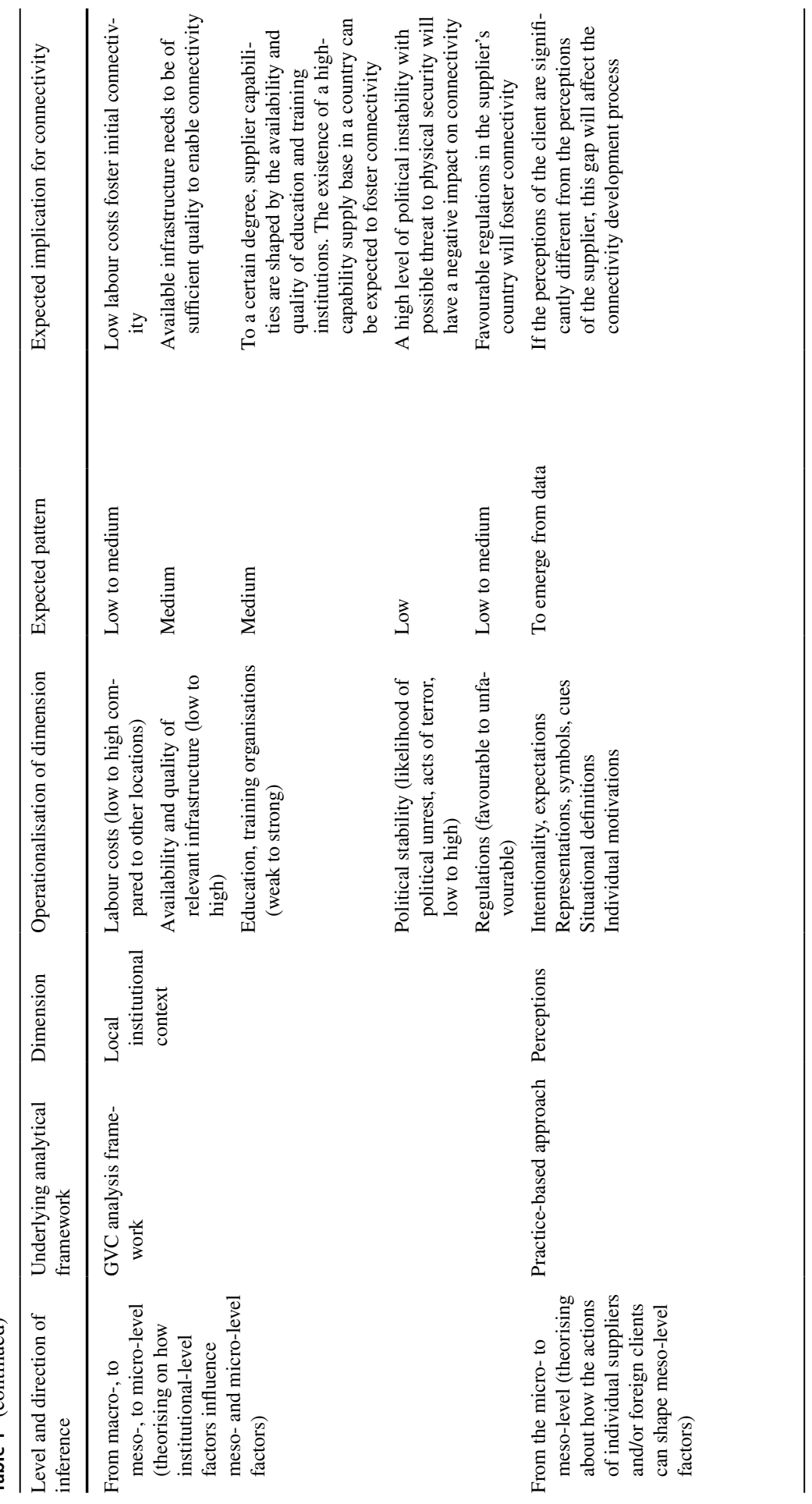




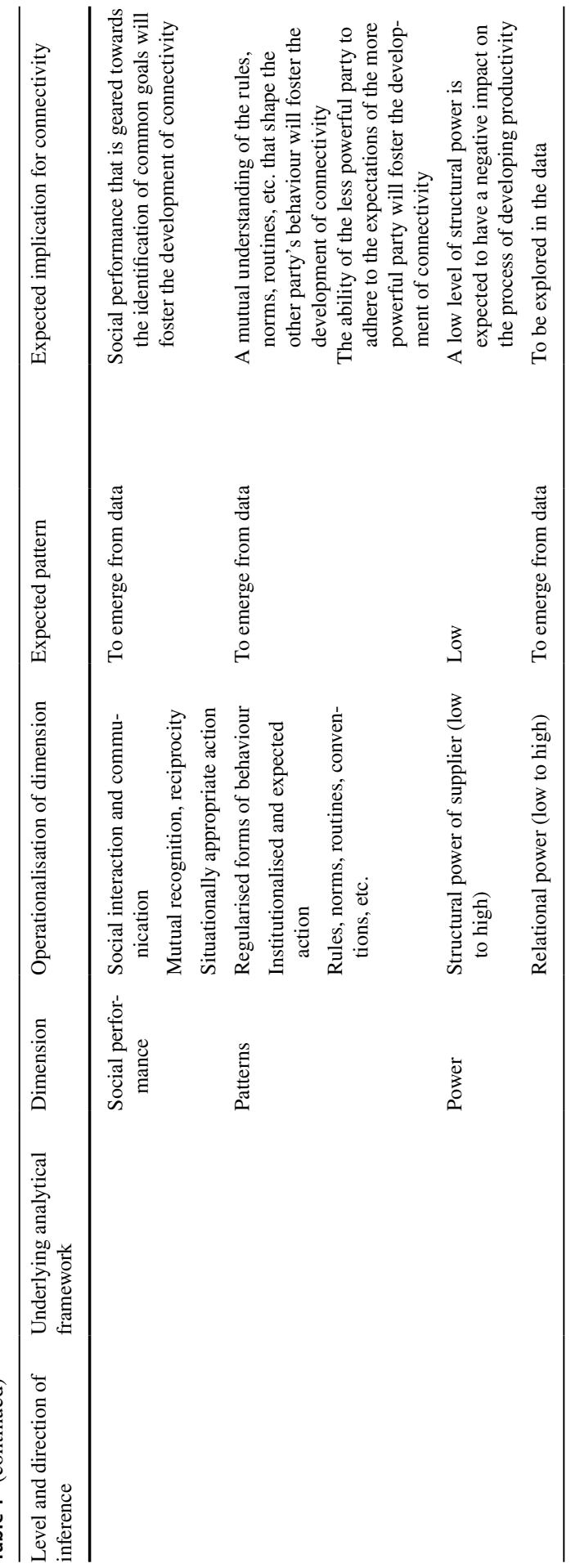


Interviewees included CEOs and senior project managers with insight into the history of their firm's business and its growth trajectory. The company profiles are shown in Table 2.

The interviews were complemented with secondary data collected from company websites, media sources, LinkedIn profiles, online software platforms, YouTube or other videos, awards and recognitions. In terms of interview questions, respondents were first asked about the history of their firm, the most critical events in its history, and the founder's background. Interviewees were invited to recall specific instances of disruption to their business and to elaborate on these events. We also asked them to recount and reflect on how they had initiated and established connectivity with their foreign clients. In order to understand the relationship between the suppliers and their clients, we invited the participants to give concrete examples that best described the nature of their interactions. The interviews were conducted by one of the co-authors, who is of Pakistani origin.

The data analysis was carried out in the software package NVivo (Sinkovics and Alfoldi 2012; Sinkovics et al. 2008). Our preliminary template served as our initial node structure. This was then updated and extended as we carried out the analysis (Sinkovics 2018; Sinkovics and Alfoldi 2012).

\subsection{The Global Offshore Services Industry}

Before we present the findings from the three pattern matches, we need to provide an overview of the two value chain configurations in our study (see Figs. 1, 2) and where they are placed within the global offshore services industry. These are quite general and characterise the relevant GVC, within which the Pakistani context is a relatively small component. As mentioned in the section discussing the overarching GVC analysis framework, GVC mapping can be used to examine how global industries are organised. Based on the skill levels and work experience of suppliers, offshore services can generally be placed into one of three broad categories, namely, information technology outsourcing (ITO), business process outsourcing (BPO) or knowledge process outsourcing (KPO). In terms of the level of value added, ITO services can be in the low-, middle- or high-value-added category. BPO services mostly stretch from the low- to the middle-value segment, whereas KPO service activities are in the highest-value segment of the GVC (Gereffi and Fernandez-Stark 2016). Our case firms belong to the ITO category and therefore do not include activities in the highest value segment of the GVC.

Another way of depicting value chains is through the 'smile of value creation' (Lorenzen and Mudambi 2010; Mudambi 2008). Software value chains generally encompass activities ranging from initial idea, requirement analysis, conceptualisation, high-level design, low-level design, coding, testing and support activities, to branding and marketing (Choksy 2015; Lema 2015; Lorenzen and Mudambi 2010). Requirement analysis and high-level design require problem-framing and advanced problem-solving capabilities (Lema 2015; Lema et al. 2015). This in turn involves continuous two-way interaction with clients in order to facilitate the understanding of user needs and the design of the software in accordance with those needs (Currie 


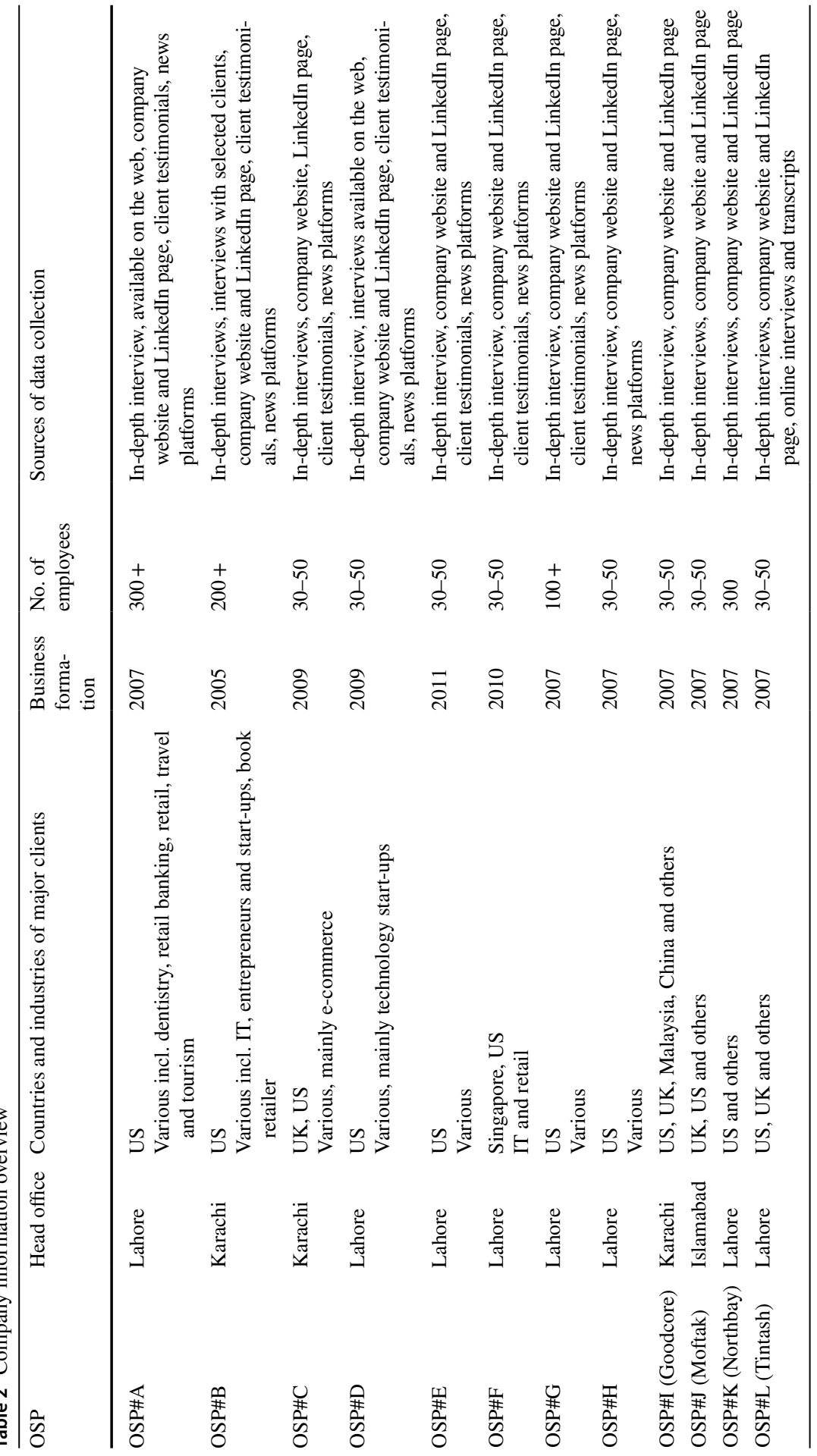




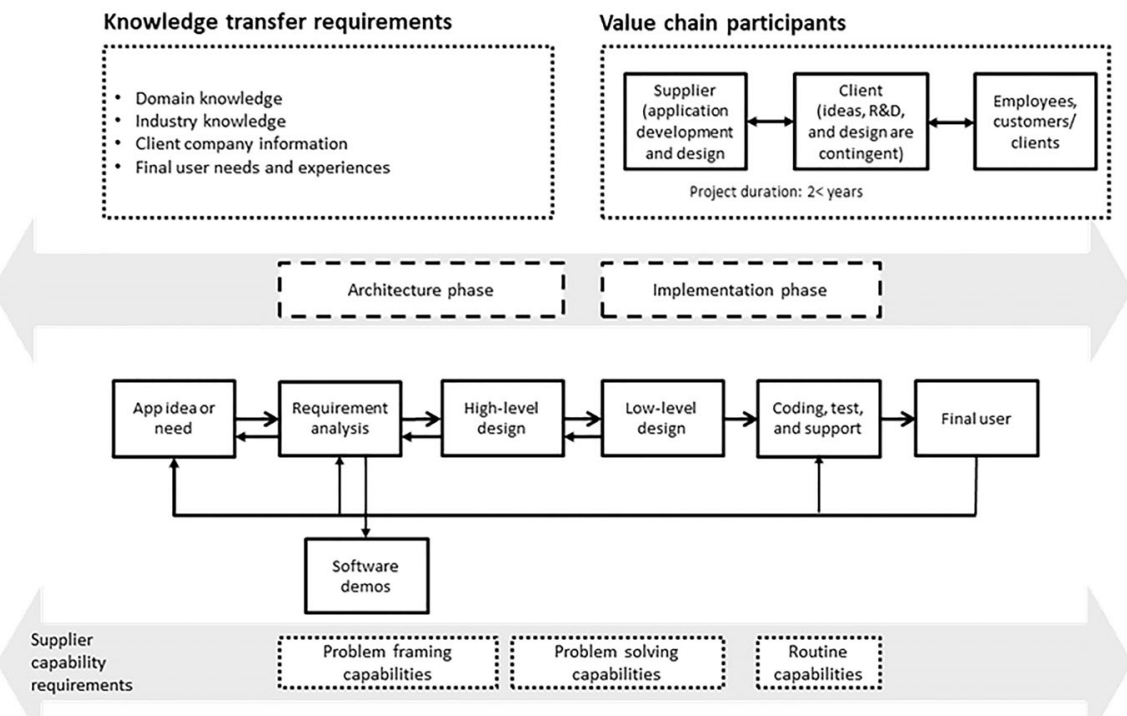

Fig. 1 B2B software solution value chain

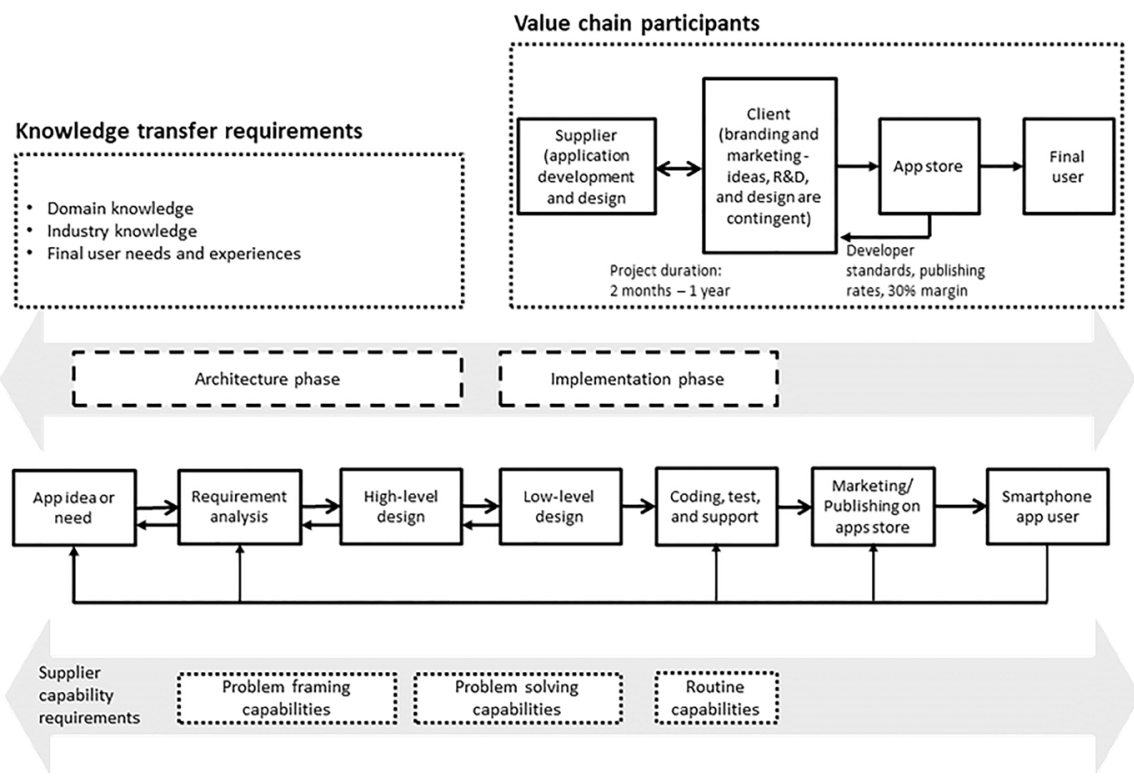

Fig. 2 B2C smartphone application value chain

and Seltsikas 2001). Routine capabilities are required for carrying out more standardised functions such as coding, testing and updates (Lema 2015; Lorenzen and Mudambi 2010). 
The difference between the two value chain configurations in our study arises from the complexity and duration of the projects (cf. Buckley et al. 2018). We labelled the first value chain, depicted in Fig. 1, the 'B2B software solutions value chain'. As the name indicates, the projects are on the traditional side of the software development process. The end product is directly utilised in the client company (Choksy 2015; He and Xu 2014; Lema 2015; Richardson 2011). Project durations range from 2 to 5 years. Software applications are developed for a range of platforms, from desktop computers to various web-based platforms, to smartphones (Currie and Seltsikas 2001; Jain and Khurana 2016; Vitari and Ravarini 2009). OSPs are required to possess relatively high levels of technical capabilities and experience (Duan et al. 2010; Duan and Zhu 2011; Lema 2010, 2011, 2015; Xudong et al. 2008). Furthermore, in order to enable the OSP to engage constructively in the problem-framing and/or problem-solving process, clients need to share sensitive data such as new product ideas, design information or other types of confidential company information (Manning 2014; Thelen et al. 2010). In terms of value segment, supplier firms in this value chain configuration are situated away from the bottom of the smile curve (cf. Gereffi and Fernandez-Stark 2016; Lorenzen and Mudambi 2010).

The second value chain configuration, depicted in Fig. 2, is labelled the 'B2C smartphone application value chain'. OSPs linking into this type of chain are contributing to projects that have shorter durations than B2B software projects. A standard application project lasts between 2 months and 1 year. However, the relationship may continue through additional orders, or if the client requires frequent application updates (Holzer and Ondrus 2011; PSEB 2010, 2012). With the emergence of the iPhone (iOS) and Android platforms, there has been a significant rise in the demand for smartphone applications (Holzer and Ondrus 2009; Kenney and Pon 2011). This is a niche area in the software sector, and one in which an increasing number of developing countries are competing (PSEB 2012). In terms of value segment, firms in the B2C smartphone application value chain are closer to the bottom of the smile curve (cf. Gereffi and Fernandez-Stark 2016; Lorenzen and Mudambi 2010).

\section{Findings}

\subsection{Meso- and Macro-Level Factors Shaping the Initial Parameters of Connectivity}

The purpose of these first two pattern matches is to identify the factors that shaped the initial connectivity parameters for our case firms. Table 3 provides an overview of each OSP's capabilities at the time of their first connection with the client, how these capabilities changed in subsequent years, the nature of the projects, the required knowledge transfer from the clients, and the type of value chain configuration the suppliers link into. This information, gleaned from the data, allows us to examine the (1) complexity of information and knowledge needed for a transaction, (2) extent to which this information and knowledge is codifiable and (3) level of supplier capabilities. Subsequently, we match the mode of governance predicted by the GVC analysis framework to the observed mode of governance. 


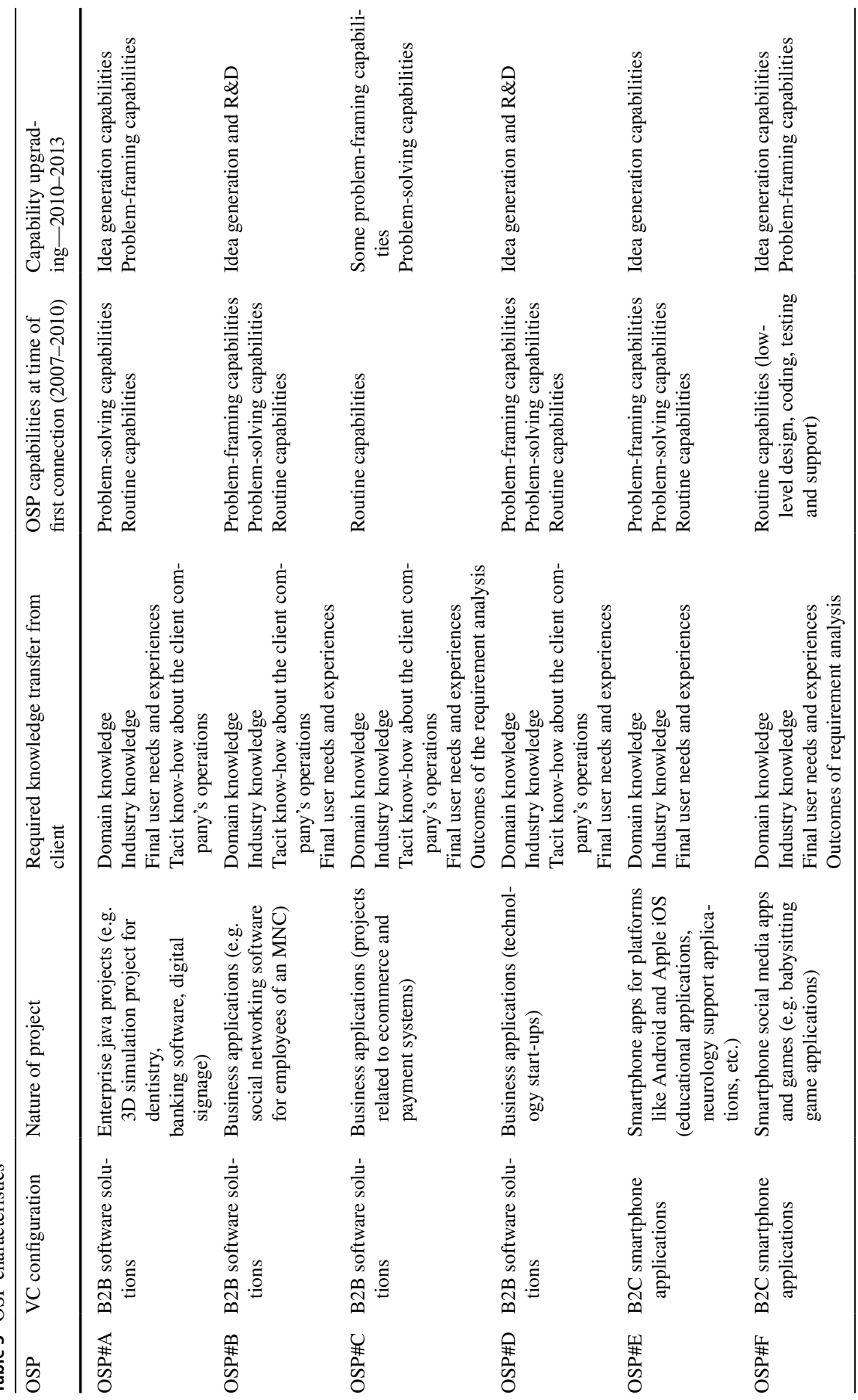




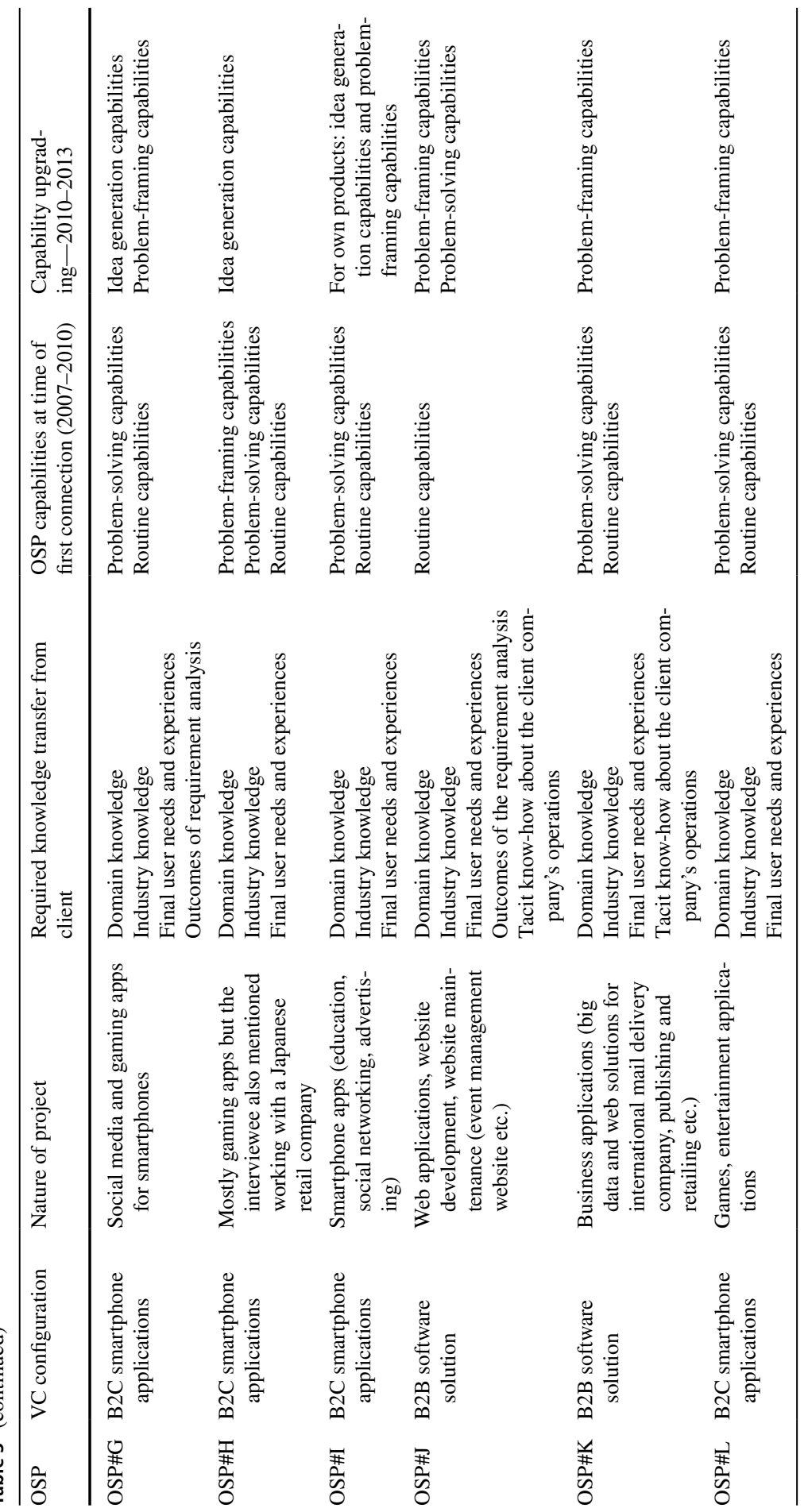


Table 4 provides an overview of the governance-level pattern match. As there was no variation in the findings across the two value chain configurations, we have summarised the results in a single table. In terms of the complexity and codifiability of knowledge, and supplier capabilities, the observed empirical patterns matched the expected patterns. However, we identified a deviance in terms of coordination and control. The initial expectation was that the anticipated relational mode of governance would reduce the need for coordination and control. Yet, we observed high levels of both, especially from larger and more established clients. The implications for knowledge connectivity manifest as low levels of initial client trust in suppliers' ability to deliver the project, and low levels of co-location. Furthermore, our analysis indicated that initiating connectivity with clients was challenging regardless of the OSP's capability. Sturgeon (2009) emphasises that the GVC governance framework is a bottom-up, research-driven method. If the data do not fit the theory, it means that other factors are at play.

To this end, we turned to investigating the impact of institutional factors on interfirm connectivity. Table 5 provides an overview of the second pattern match. As anticipated, the most important impact stems from the political instability of the country. Clients' fear of travelling to Pakistan, and the difficulties OSP employees face when they attempt to leave Pakistan-perhaps an extreme form of the 'hassle factor' (Schotter and Beamish 2013)_pose significant constraints on the development of client trust through co-location.

"It is good for people from both sides of a partnership to travel back and forth and meet each other from time to time. Being located in Pakistan, it can be difficult for both our clients and us to do so. Visas on both sides can be problematic. Even if our partners are willing to visit us, and their visas are granted, their families are hesitant because of the general perception of Pakistan. Lack of security, and even grimmer perceptions of it around the world, really hurt the prospects of more people travelling to, or doing business in, Pakistan" (OSP\#A).

Given the differences in nature of the two value chain configurations, the importance of certain dimensions also varies across the two. For example, client trust in suppliers' overall competence and the existence of local institutional conditions supportive enough to ensure the completion of the transactions, are especially relevant for B2B software solution value chains. As depicted in Fig. 1, foreign clients are often required to transfer sensitive data to OSPs. Pakistan's negative image and high propensity for instances of physical violence make potential clients reluctant to hire Pakistani OSPs. The longer average duration of these projects, as opposed to those in the B2C mobile application value chains, and the sensitivity of transferred knowledge, heighten the risk perceptions of clients even further:

"Most clients are risk averse. The reason is that they give out time- and mission-sensitive product development contracts. Pakistan has a very unfavourable risk profile, comparable to Iraq, Afghanistan or Somalia. If your country's reputation is like this, very few companies are willing to do business with you" $(O S P \# C)$. 


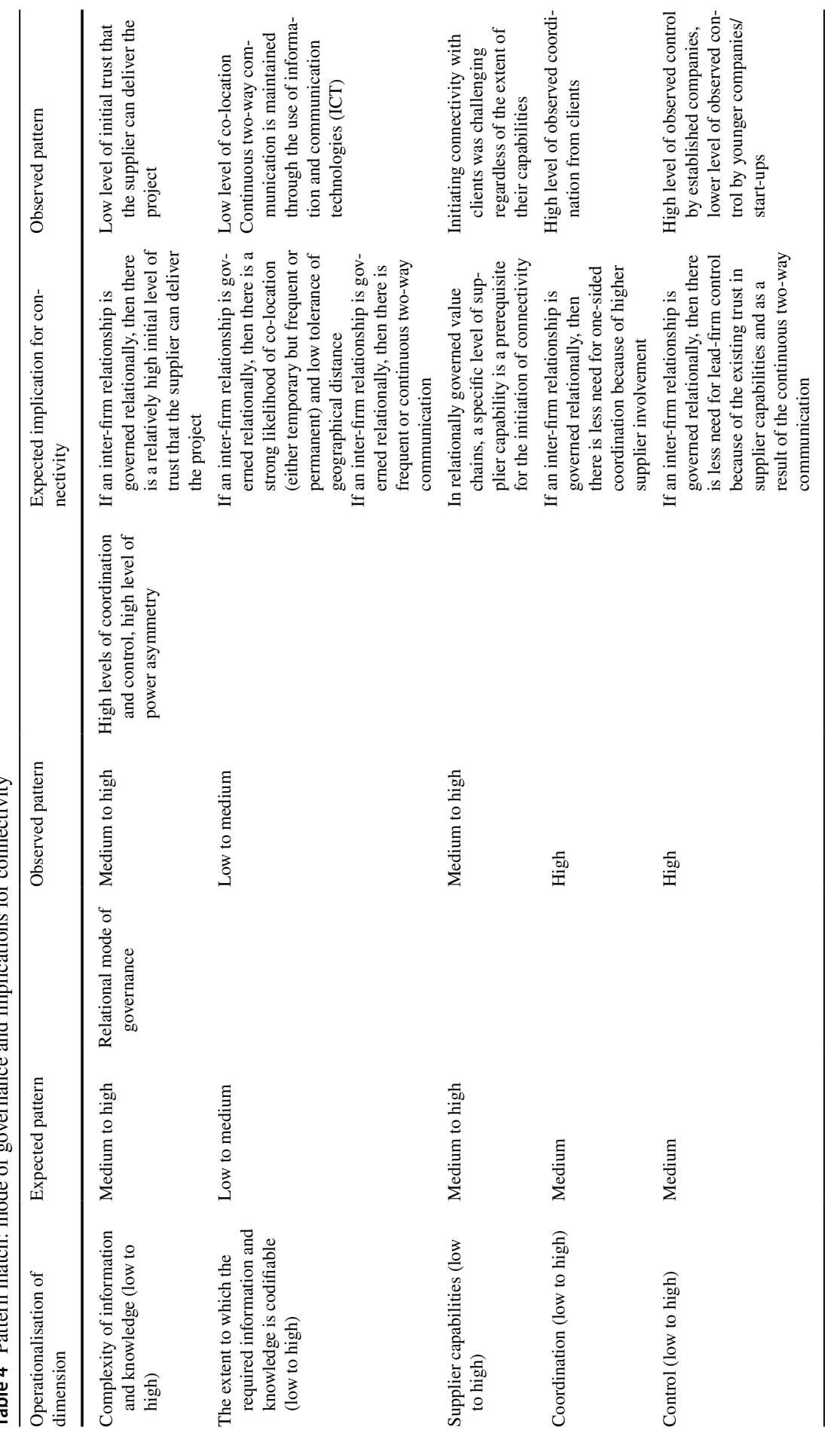


In contrast, OSPs linking into B2C mobile application value chains face lower barriers to initiating connectivity due to the shorter duration of the projects. This is, however, only the case when the offshored activities are standardised, such as with programming, testing and application updates. These transactions tend to be more easily codifiable, and the information and knowledge required for the transaction less complex. As a consequence, such relationships are governed in a more modular than relational way. The associated risk is lower. However, OSPs aspiring to link into B2C mobile application value chains face similarly high entry barriers to their counterparts in B2B software solution value chains when the offshore activities involve highvalue-added services, such as planning, requirement analysis and software design.

The findings from this macro- and meso-level pattern match seem to be in line with the explanation supplied by Jensen and Petersen's (2013) process model about the importance of managers' comfort zone to global sourcing decisions, as well as the more direct influences of project duration on organisational form (Buckley et al. 2018). In the next section, we turn to the investigation of how these OSPs addressed these meso- and macro-level issues that heightened clients' risk perceptions and thus reduced their comfort zone.

\subsection{OSP Practices and Implications for Connectivity}

Tables 6 and 7 provide an overview of the third pattern match. By exploring the four dimensions of practice in each value chain configuration, we were able to identify two respective strategies. OSPs connecting to B2B software solution value chains had implemented what we term a 'step-up' strategy (see Table 6), whereas OSPs linking into B2C smartphone application value chains had followed a 'break-out' strategy (see Table 7). The difference in the OSPs' approaches to addressing the challenges they faced was partially shaped by the nature of the projects, and partially by the founders' individual motivations. While OSPs adopting a step-up strategy sought to build long-term relationships with their foreign clients, those following a break-out strategy regarded their relationships with foreign clients as a stepping stone towards their independence. The rest of this section will discuss the differences between these two strategies.

\subsection{Step-up Strategy and Connectivity in B2B Software Solution Value Chains}

We named this strategy 'step-up' because of the way the OSPs 'stepped up their game' to address the challenges they encountered. It includes a range of practices/ actions aimed at building legitimacy, trust and capabilities geared towards developing and maintaining long-term relationships with clients. In the previous section, we described how the adversity of the local institutional environment had shaped potential clients' risk perceptions and, as a consequence, their attitudes towards Pakistani OSPs. Table 6 unpacks this in more depth. It disaggregates both client and OSP perceptions into smaller units and attempts to reconstruct the interactions between these units. For example, clients' risk perceptions were shaped by a number of cues, including media reports of terror attacks, the statements of politicians, and country risk ratings. The 
cues alerting OSPs that they needed to take alternative action if they were to survive include the increasing difficulty of securing appointments with potential clients and the withdrawal of foreign investors. According attention to cues in the analysis process is important because they influence how individuals interpret situations (cf. Hammond 1966). This in turn plays a significant role in their decision making.

"If we went directly to clients and we pitched to them as a Pakistani company, they would not pay attention to us because, if that was the only thing they knew about you, they would not decide in your favour. Obviously, we have a huge negative image problem in the world. We have grown organically using references, because that makes potential clients open to at least listen[ing] to our pitch. They may still think that being from Pakistan is a problem, but the fact that someone else has had a great experience with us helps offset the negative image problem" (OSP\#A).

Clients feared the loss of important data, ideas, and other intellectual property rights. They also expected coordination difficulties and limitations on traditional risk reduction strategies due to impaired geographical mobility (cf. Jensen and Petersen 2013). For OSPs, the correct decoding of clients' concerns led to the realisation that they needed to find a way to mitigate these negative impacts. In order to identify an effective strategy, it was important to understand the intentions, expectations, and motivations of potential clients. They also needed clarity about their own intentions, expectations and motivations.

Furthermore, taking effective action to positively influence clients' comfort zone also required the analysis and understanding of the rules, norms, routines and conventions (see patterns in Table 6) that guide clients' perceptions and decision making, and the ensuing expectations of what constitutes acceptable OSP behaviour. For instance, clients adopted more stringent assessment criteria when it came to Pakistani OSPs, based on a set of formal and cognitive cues. Examples of formal cues included a strong portfolio and the accumulation of favourable references. In terms of cognitive and symbolic cues, the trustworthiness of OSPs was determined based on behavioural dimensions such as honesty and eagerness to comply with client specifications. In the connectivity maintenance phase, OSPs sought to reduce the negative impact of limited mobility by adopting virtual coordination mechanisms facilitated by information and communication technologies (ICT). This offered clients an alternative to in-person socialisation processes as a risk mitigation strategy (cf. Jensen and Petersen 2013).

A step-up strategy is additionally characterised by a long-term orientation. This observation is in contrast to the expectation that firms from economies with high levels of environmental risk would tend to prioritise short-term gains over riskier long-term investments (cf. Bilgili et al. 2016). A partial explanation is supplied by the business owners' motivation to find ways of aiding their long-term survival and growth and ways to increase their feeling of self-worth. The rationale is that, over time, they can demonstrate that they have the necessary capabilities and understanding, and the right attitude. This, in turn, will bring in larger projects. To obtain their long-term goal, OSPs were willing to take on smaller, peripheral projects as an intermediate step towards gaining access to networks and markets. Additionally, 
the nature of the service in this sector is conducive to ICT reliance that, in turn, to a degree and under certain circumstances, can be used to bypass barriers to connecting to GVCs (cf. Pezderka and Sinkovics 2011; Sinkovics et al. 2013; Yamin and Sinkovics 2006).

The power dimension in Table 6 is important because it shapes the parameters of connectivity within the relationship. When clients hold all or most of the structural power in the relationship, their needs and preferences suppress those of the suppliers (cf. Hoque et al. 2016). In other words, the level of mutuality and reciprocity is low in the relationship and there is no or only limited two-way communication. However, over time suppliers can build relational power by demonstrating their value to clients (cf. Sinkovics et al. 2018). This increase in trust and social capital in turn introduces more mutuality and reciprocity into the relationship.

\subsection{Break-out Practice and Connectivity in B2C Smartphone Application Value Chains}

Table 7 provides the details of this analysis. We named this strategy 'break-out' because of the OSPs' desire to become independent and focus on the development of their own products once they had built up the necessary knowledge base and capabilities, and/or financial capital. Due to space limitations, we focus on the main characteristics of this strategy. Despite the negative influence of Pakistan's country image, clients' risk perceptions were mitigated by the short duration of the projects, the lower complexity of the knowledge transfer, and cost savings. Although a breakout strategy is also characterised by a long-term orientation, there is a difference with respect to the OSPs' underlying motivation and how they view their social self. Contrary to suppliers in B2B software solution value chains, OSPs in this type of value chain view their engagement as an intermediate step towards their final goal. They do not perceive themselves as inferior or less powerful.

Notwithstanding this, in order to successfully gain entry into the value chain, it was necessary for these OSPs to achieve an understanding of the dominant rules, norms, routines, conventions and expectations within the chain. Similarly to the OSPs in B2B software solution value chains, they compensated for reduced geographical mobility with ICT-based coordination mechanisms. Transparency and honesty were also key in convincing potential clients of their trustworthiness.

"I fly to attend a few conferences to connect with new clients. The thing is that we are very transparent about our expertise, our resources and everything. Many people do not want to be associated with Pakistan and, to be honest, there is an issue with being from Pakistan. However, we are extremely honest with our clients. We assure them that, if they decide to give us the contract, we have the necessary technical expertise and human resource base. If we are honest and if we do not play games with our clients, we have an edge. If we do not show them something we are not, then it does give us an advantage in the long term".

With respect to the power dimension in the analysis, we observed a difference in this value chain configuration. Due to their different motivation, these OSPs do not 
try to shift the power by focusing on trust and social capital building. Their priority is to acquire the necessary means, both in terms of knowledge and finances, to be able to break free from this sourcing relationship. When that happens, it is up to the client to either invest in the relationship to keep the OSP in the value chain, or to search for new suppliers. The latter choice will entail search and set-up costs.

\section{Discussion and Conclusions}

This paper investigated how 12 Pakistani OSPs had survived and grown despite their adverse home country context. Theoretically, we framed the study against CanoKollmann et al.'s (2016) invitation to investigate the process of the development of connectivity in and across space. Analytically, we drew on Gereffi and FernandezStark's (2016) GVC analysis and Jones and Murphy's (2011) practice frameworks to complement insights from Jensen and Petersen's (2013) process model of transformational global sourcing. Based on the findings from the case analysis, we created a dynamic framework of the factors shaping the degree of connectivity and transformational global sourcing over time (see Fig. 3). The framework simultaneously looks at the lead firm and supplier sides. Furthermore, it attempts to capture the interaction of micro-, meso-, and macro-level concepts in the connectivity development process, as well as the possible impact on the degree of transformational global sourcing.

We propose that the complexity of the transactions, the codifiability of information and knowledge necessary for the transaction and the level of supplier capability at the time of contact initiation will have an impact on the extent to which lead firms are initially willing to invest in building connectivity with a prospective supplier. This is in line with what can be deduced from Gereffi et al.'s (2005) propositions in their governance framework. However, as discussed in the conceptual background part of this paper, there are a number of factors that moderate this relationship. In Fig. 3, we propose a moderating effect of the comfort zone of lead firm decision makers, in line with Jensen and Petersen (2013). In doing so, we provide a more detailed list of constructs shaping lead-firm managers' comfort zone in an adverse context, namely the four dimensions of the practice framework (Jones and Murphy 2011, also see Tables 6 and 7 for more detailed insights), assignment duration (Buckley et al. 2018), and whether or not ICT can be used to coordinate and control the relationship with the supplier. This latter dimension seems to be particularly important in an adverse environment, where physical face-to-face interactions are difficult.

However, the investment in building connectivity is not necessarily a one-sided decision. Depending on their initial strategic intent regarding what they would like to gain from their relationship with the lead firm, suppliers will also make investments in building connectivity. Our findings reveal two supplier strategies (step-up and break-out, G4 and G5 in Fig. 3). Accordingly, suppliers with a step-up intent are expected to invest more into building connectivity. Additionally, they will make greater efforts to increase the comfort zone of lead-firm managers. How effective 


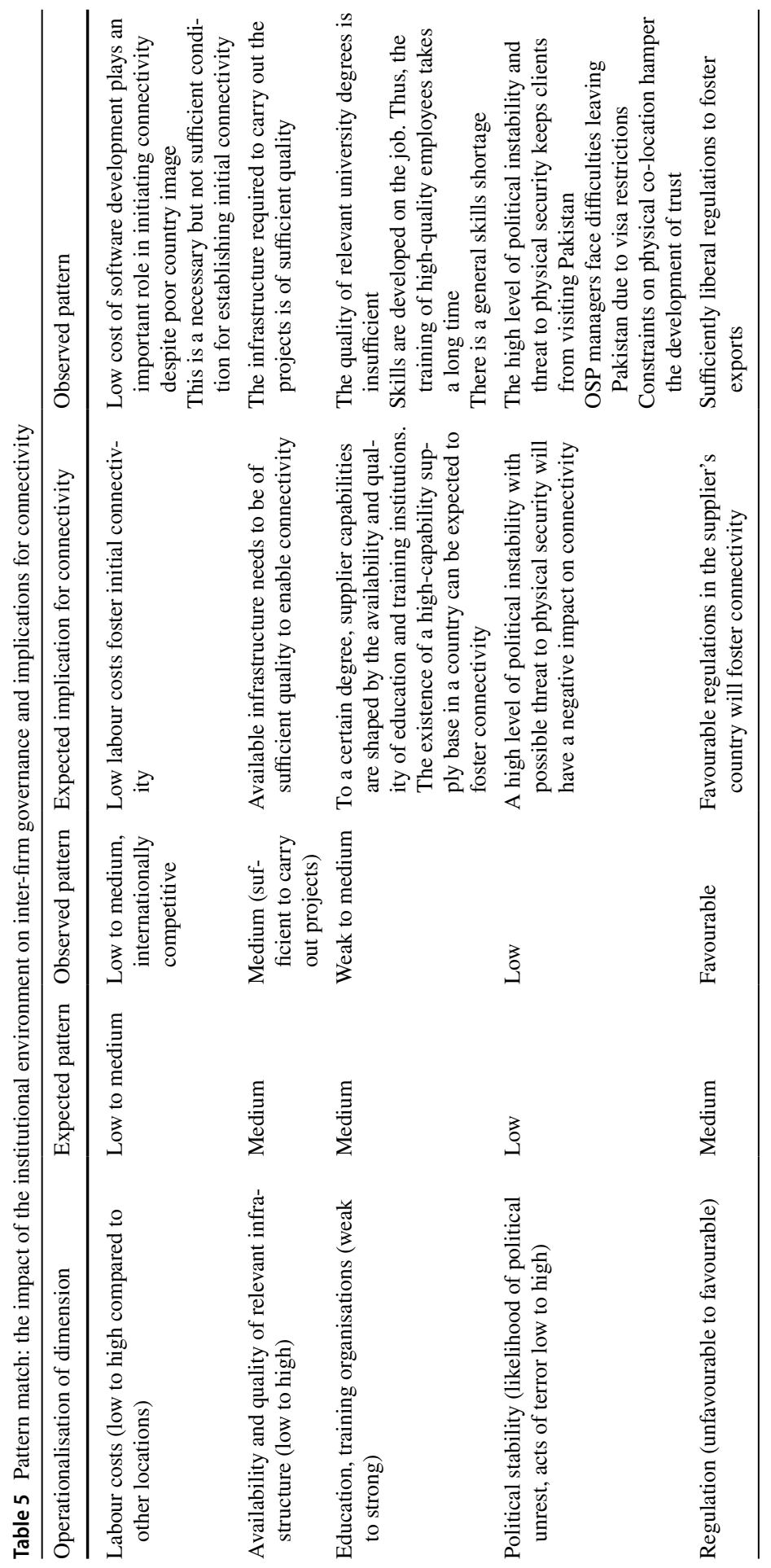




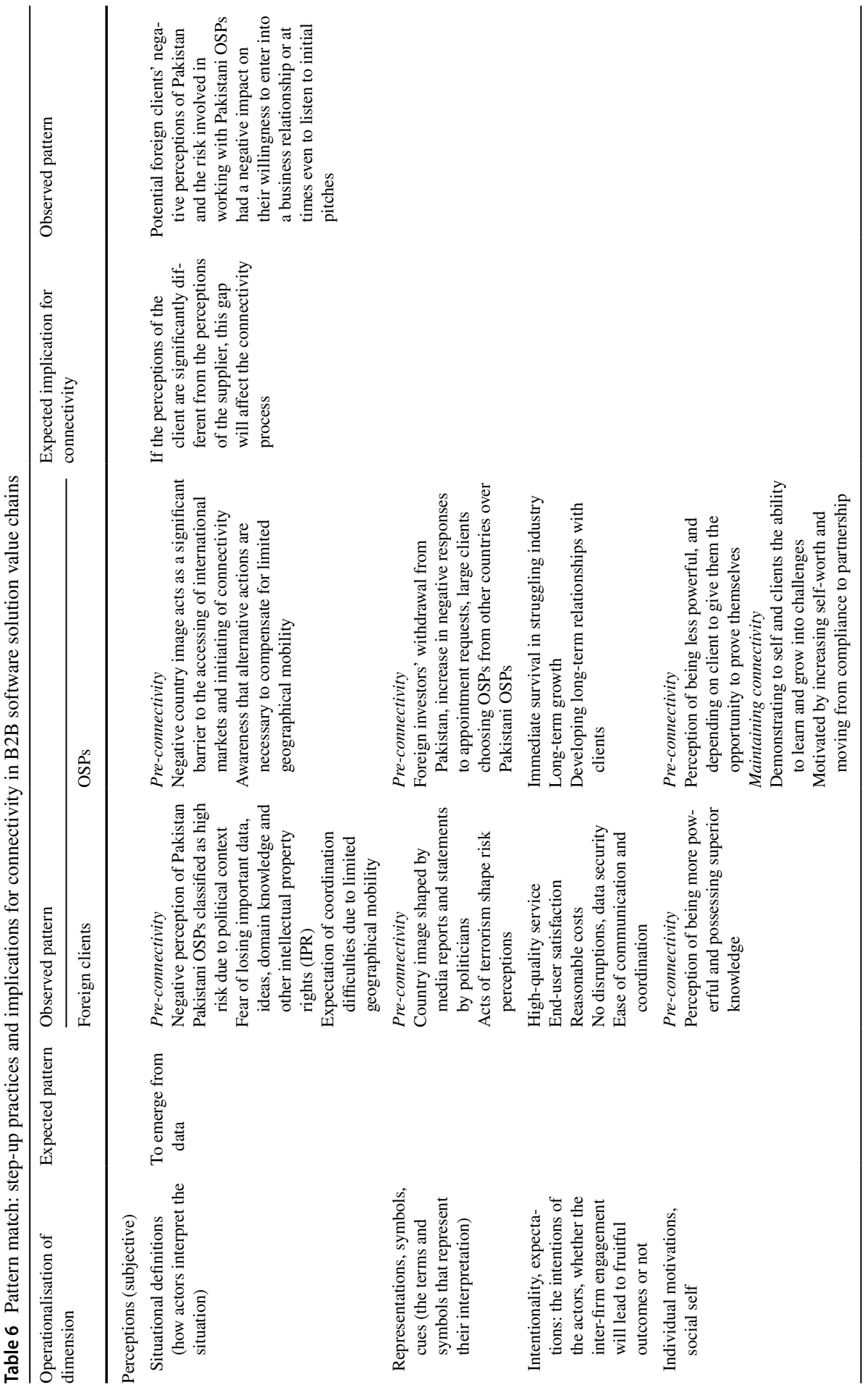




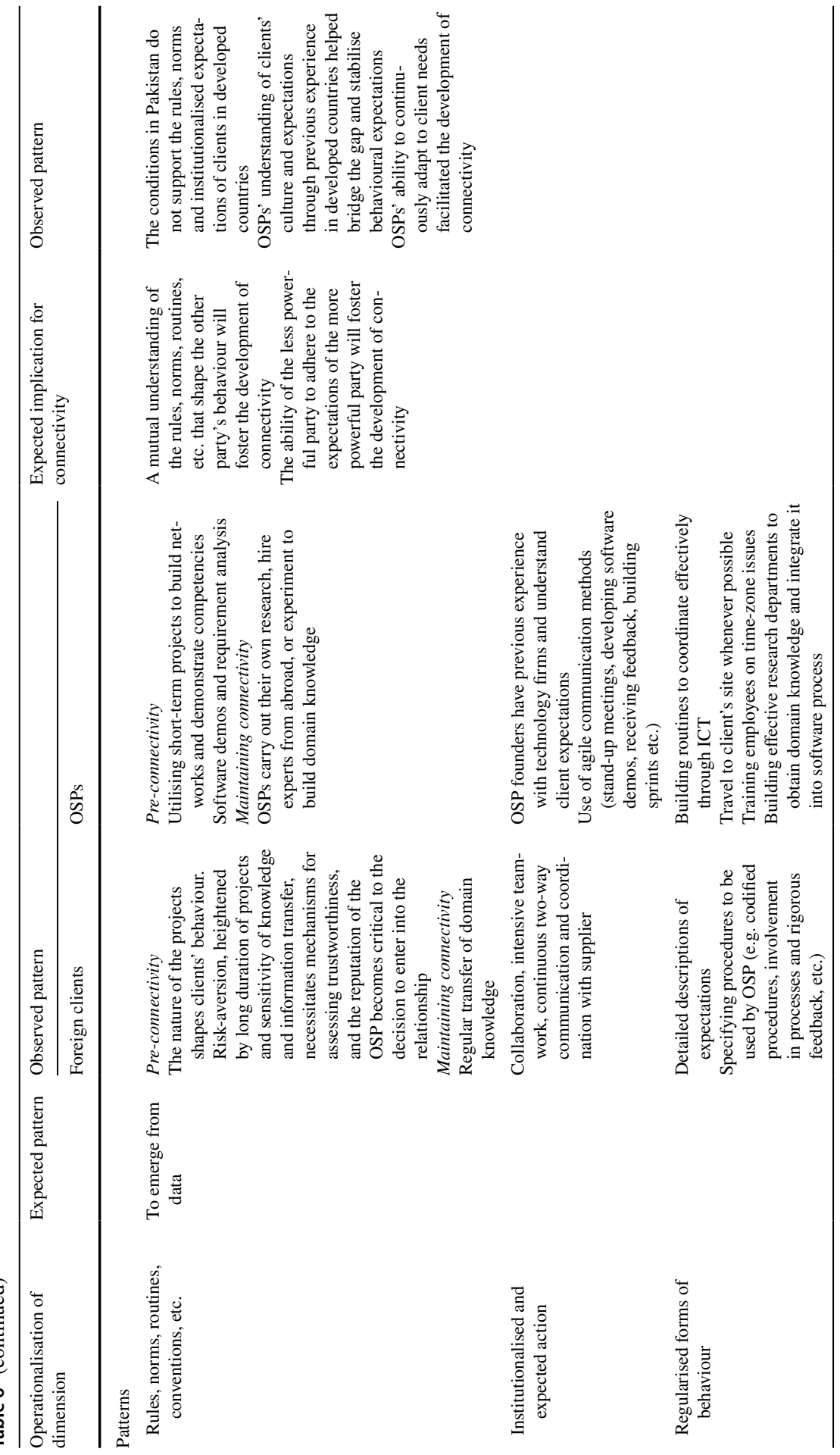




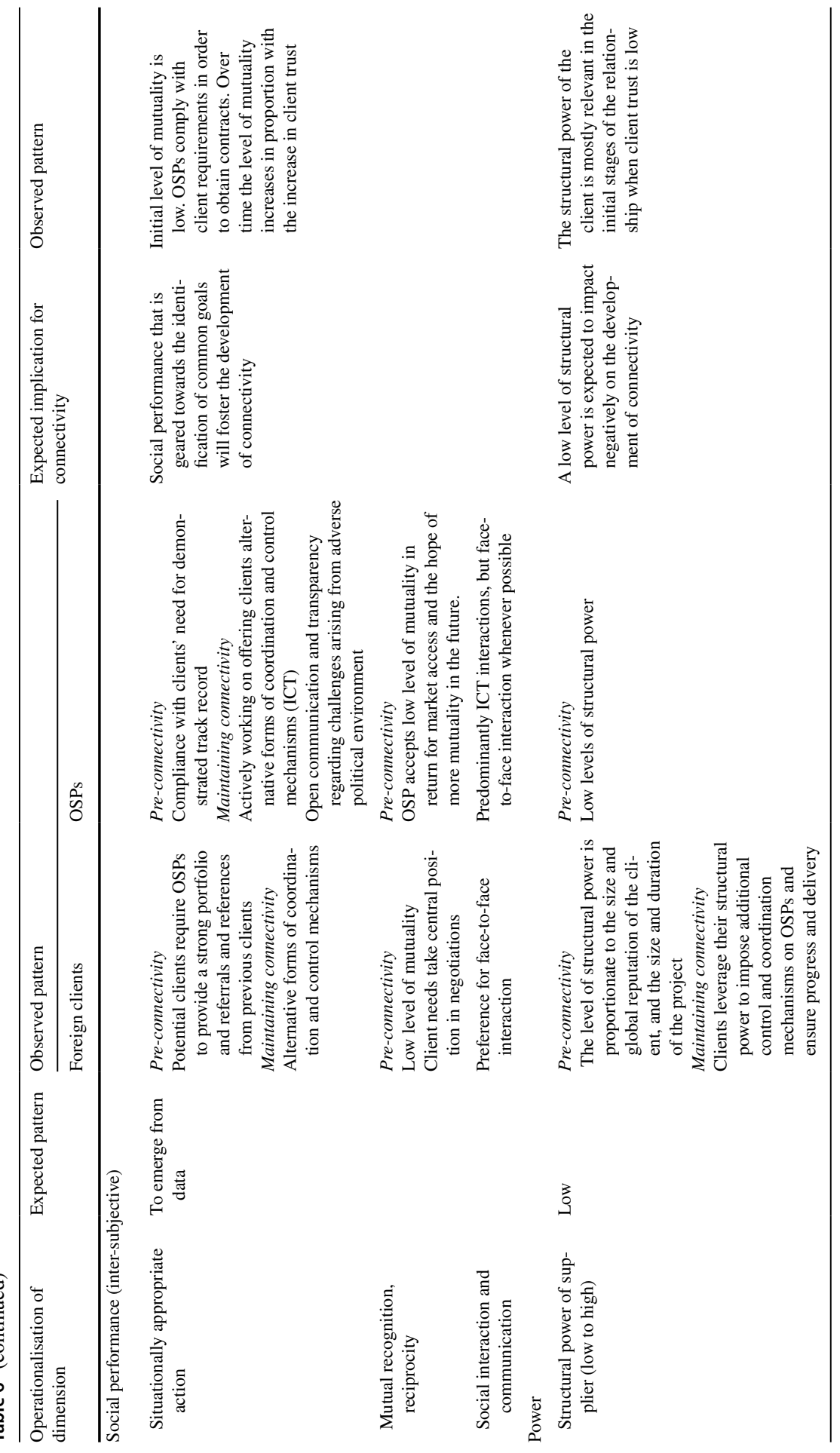




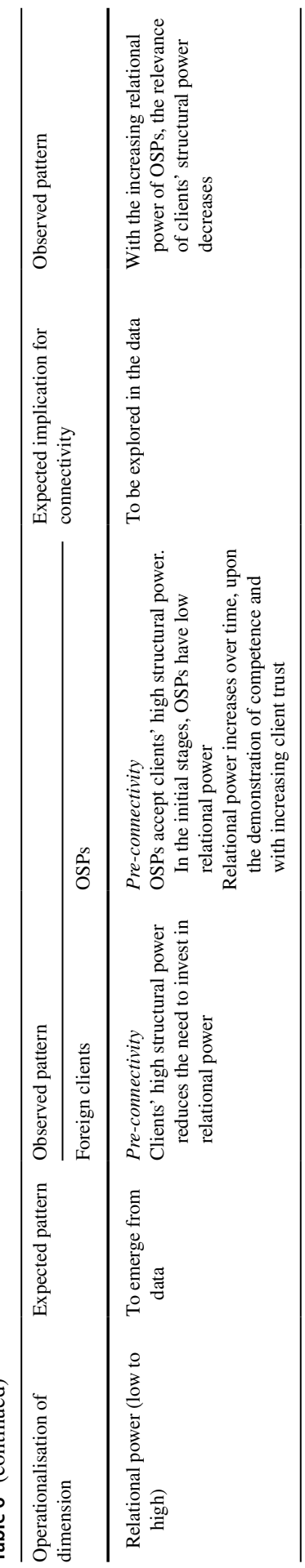


their efforts will be, is influenced by the four dimensions of the practice framework (see Tables 6 and 7 for in-depth insights).

For example, their ability to correctly decode the rules, norms, routines and conventions that drive the expectations of the lead firm (patterns, P1 in Fig. 3) is proposed to significantly shape the effectiveness of their efforts. A similarly important factor seems to be suppliers' ability to take actions that are deemed situationally appropriate by lead-firm decision makers (social performance, P2 in Fig. 3). Furthermore, the accuracy of suppliers' perceptions (P3 in Fig. 3) of the challenges they face is expected to translate into appropriate action to tackle these challenges, thus contributing to the effectiveness of their efforts to change client perceptions. Lastly, at the beginning of a client-supplier relationship in an adverse environment, it can be expected that the client will have significant structural power (P1 in Fig. 3, leadfirm side) over the supplier. However, a longer assignment duration (BCM in Fig. 3) may provide the supplier with sufficient time to build legitimacy and trust (relational power, P4 supplier side in Fig. 3), that in turn could reduce the structural power (P1 lead-firm side in Fig. 3) of the lead firm over time. Suppliers' strategic intent is also proposed to influence the nature and extent of their capability development that, in turn, can change the nature of the assignments received from the client (G1-G3 in Fig. 3). On the other hand, if suppliers' main intent is to break out of the value chain, then they will be expected to invest less in the building of connectivity. They will also make less effort to develop relational power and to increase the comfort zone of the lead-firm decision makers.

\subsection{Contribution to the Literature}

The body of literature on developing countries has witnessed significant growth in recent decades. However, most studies engage with large emerging-market multinationals (EMNEs) from relatively stable political contexts (Bilgili et al. 2016; Hoskisson et al. 2013). Alternatively, they look into how developed-country MNEs identify and tap into pockets of excellence in developing countries (cf. Cano-Kollmann et al. 2016), how they decide what constitutes the best location for offshoring (cf. Doh et al. 2009) or how they coordinate and control their value chains (cf. Buckley and Strange 2015). Furthermore, studies focusing on catch-up processes tend to adopt a more macro-level approach to explanation building (Awate et al. 2012; Kumaraswamy et al. 2012; Lorenzen and Mudambi 2010). In other words, they look at industry- or cluster-level generalisations about connectivity and the catch-up process. As a consequence, the micro-level strategic agency of smaller suppliers is comparatively under-investigated (cf. Choksy 2015; Choksy et al. 2017; Hoque et al. 2016). To this end, our study makes two over-arching contributions. First, by choosing Pakistan as the study context during an exceptionally turbulent time period, we contribute to the literature on traditional emerging economies that face challenges in the process of emergence due to high environmental risks (see also Dai et al. 2013). Second, our research contributes to the catch-up literature by probing into its micro-foundations. The relevance of this angle is that it complements the strategic agency of the lead firms (see left side of Fig. 3) with that of the suppliers (see right side of Fig. 3). 


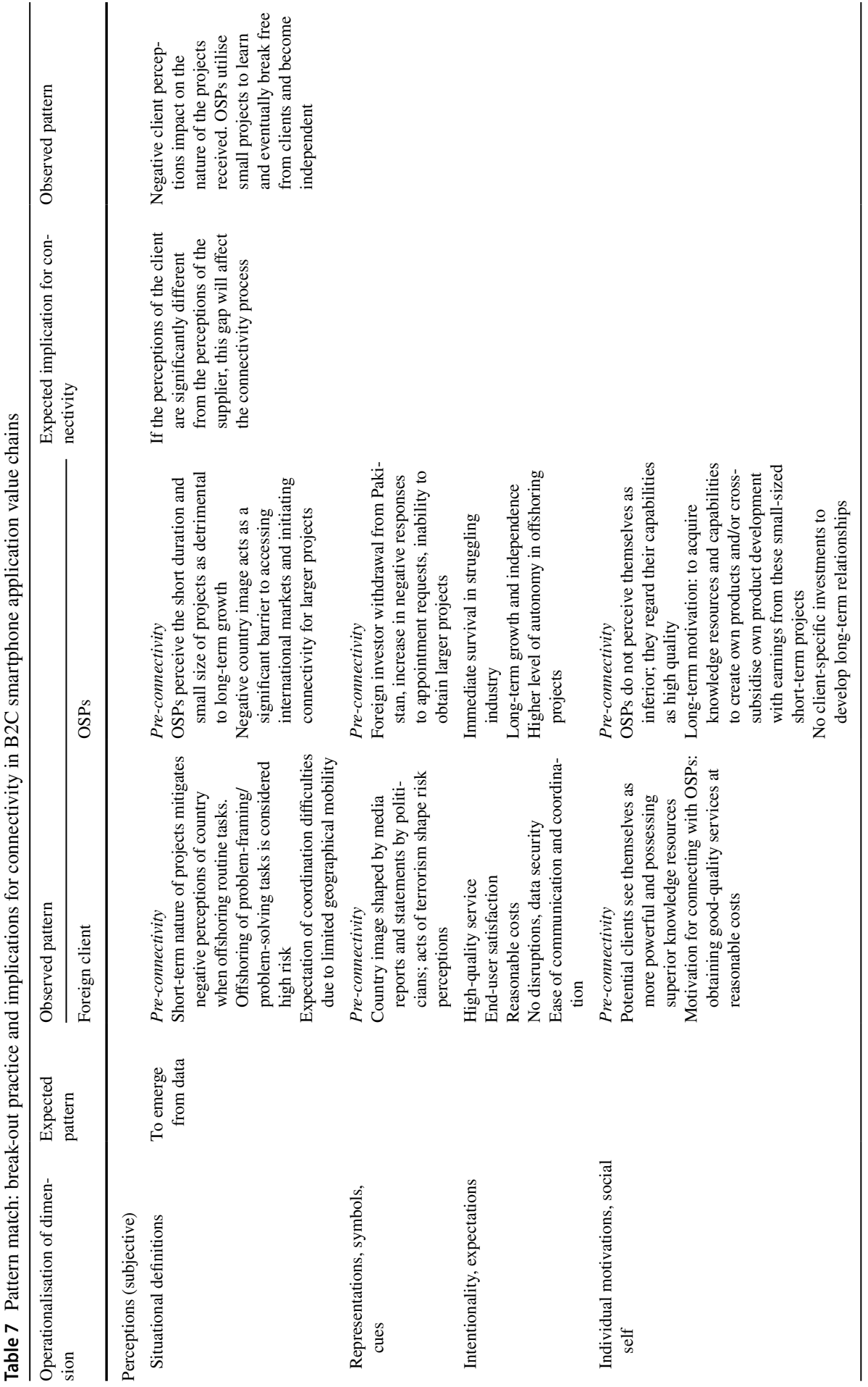




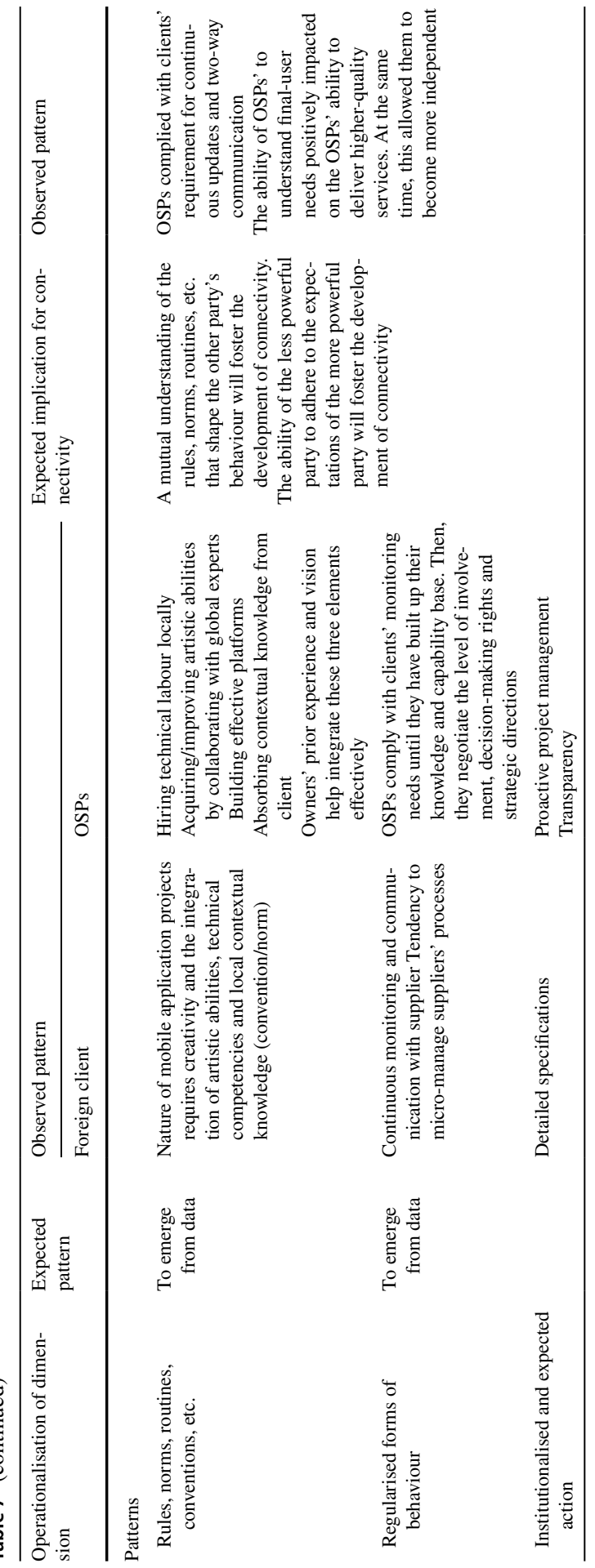




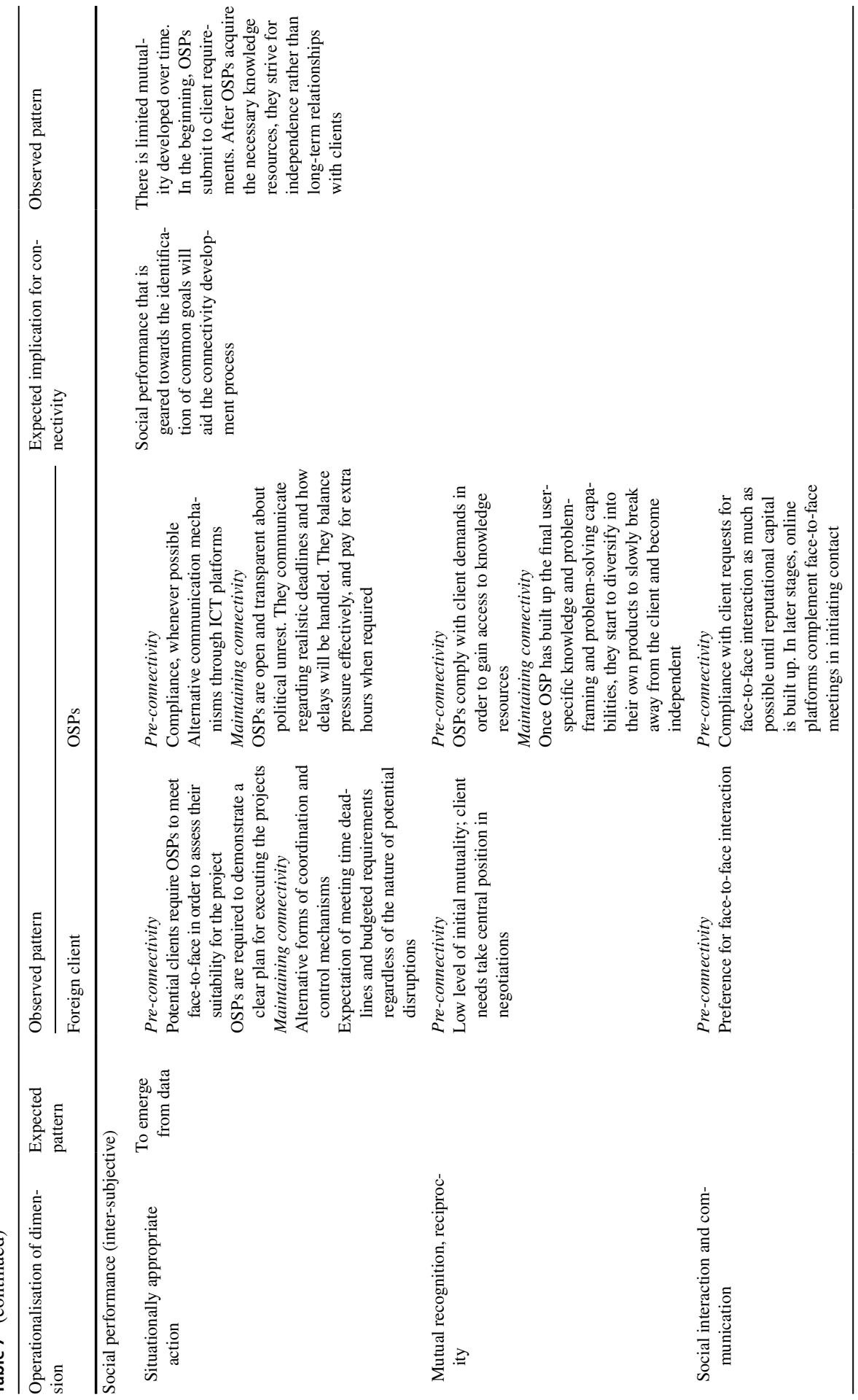




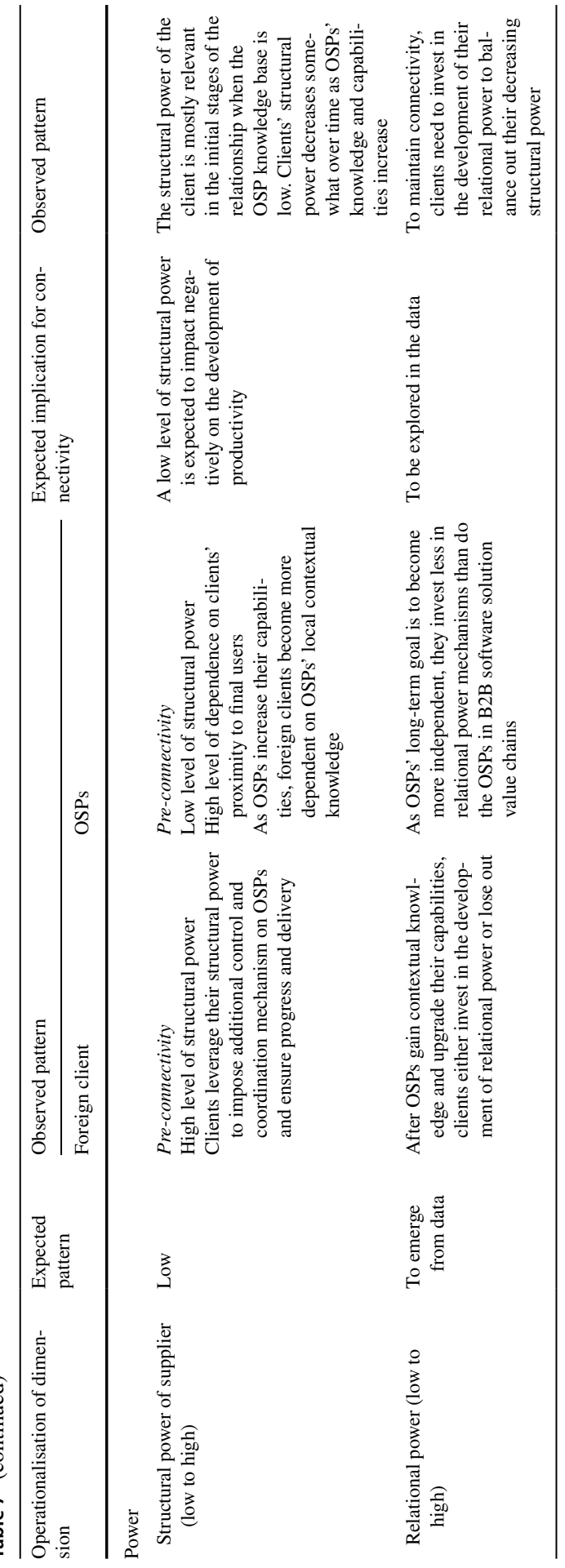




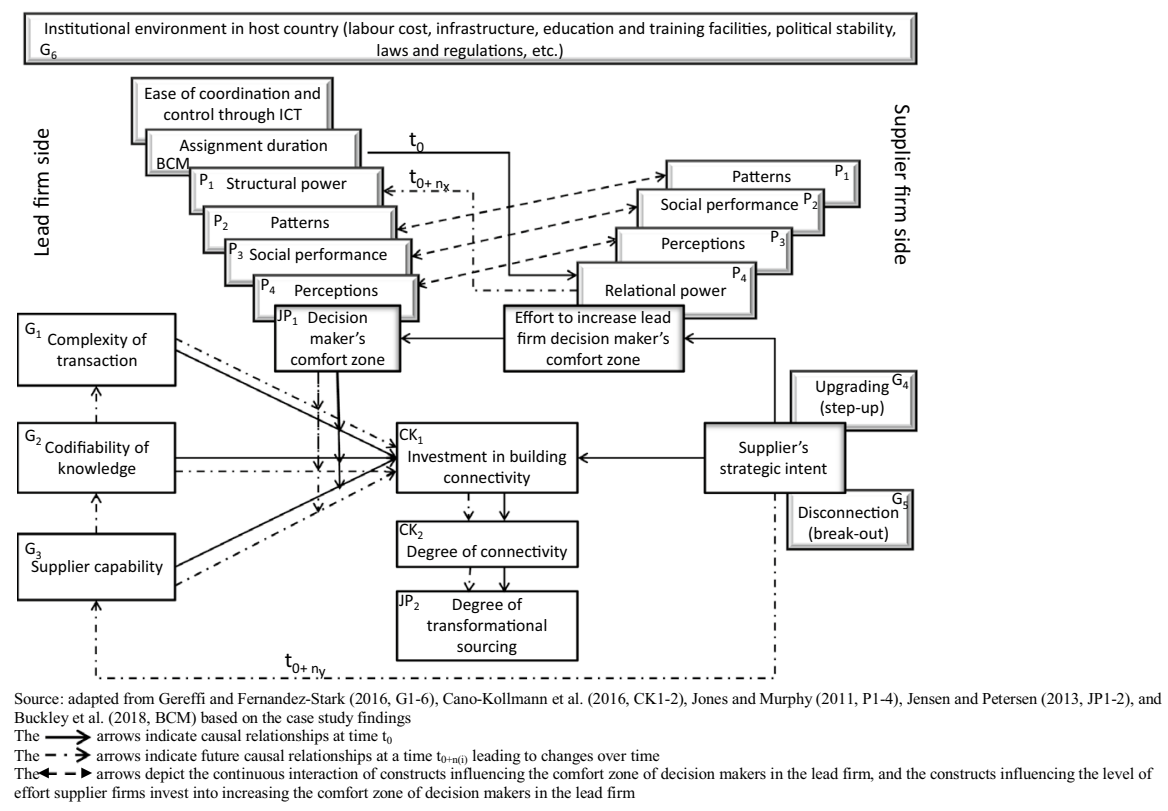

Fig. 3 Dynamic framework of the factors shaping the degree of connectivity and transformational global sourcing over time

\subsection{Managerial Implications}

Unlike manufacturing sectors, activities within software value chains are highly coupled, and it is hard to draw clear boundaries between production activities and design activities (Lema 2011; Rousseva 2008). The requirements in the software industry are primarily based on broad expectations, requiring high levels of tacit interaction (Lema 2010). The client's specific needs emerge through a process of communication between the OSP and the client (Currie and Seltsikas 2001). Therefore, it is critical for the clients to engage in continuous two-way interactions, in order to brainstorm with the OSPs, discuss plans of action and ensure progress (Hannigan and Mudambi 2015; Manning et al. 2015). However, when OSPs are operating under adverse environmental conditions, they will face challenges to developing effective coordination and communication mechanisms that will support connectivity with their clients (Choksy 2015; Manning et al. 2015). This is because travel to clients' countries is frequently obstructed through visa restrictions (Czinkota et al. 2010; Manning 2014; Schotter and Beamish 2013). At the same time, the fear of threat to physical security reduces the clients' willingness to travel to a country with an adverse environment (Richardson 2011; Thelen et al. 2010).

As a consequence, OSPs aspiring to link into software value chains face higher barriers to entry than OSPs from more politically stable countries. In addition to convincing clients that they have sufficient capabilities to carry out their projects, these OSPs need to overcome the negative country image in terms of physical security. The practice-based approach applied in this study could be a useful tool for 
managers wishing to determine how aligned their current strategies are to their goals as OSPs. Firms operating in adverse environments should engage in an evaluation process so as to understand how their perceptions and routinised actions, derived from local rules, norms and conventions, differ from those of their clients. By recognising these differences, they will be able to better understand their clients' expectations. This in turn will contribute to the identification of the most appropriate and desired action in their social interactions with their clients. Over time, OSP conduct and actions, guided by awareness of these differences, will lead to increased client trust and eventually to increased reciprocity. This will be reflected in the development of relational power over time, which could contribute towards reducing the negative impacts of the OSPs' initially low structural power. In other words, our findings should encourage OSPs to consider actively addressing the constraints emerging from their institutional environment, as an organic part of their overall strategy. For example, OSPs need to be able to construct a well-functioning technological space as an alternative to physical proximity.

\subsection{Limitations and Implications for Future Research}

Our study has several limitations. The sample underlying the empirical investigations consisted of 12 cases. Given the exploratory nature of the study, the small sample size does not pose a problem for our theorising efforts. Yet, future research may wish to derive hypotheses from our dynamic integrative framework and test them on larger, more representative, samples.

Another limitation of this study is that the analysis relied solely on the accounts of the OSPs. To mitigate this limitation, we tried to triangulate by drawing on secondary data such as client testimonials on OSP websites and LinkedIn pages. Future research that successfully negotiates access to both parties might help provide an even greater understanding of the nature of these dyadic relationships.

Acknowledgements We gratefully acknowledge comments received from Mo Yamin, Marcelo CanoKollmann, the editor Joachim Wolf and two anonymous reviewers, which greatly helped the development of the paper. Financial support was received from the University of Manchester 2014 ESRC Impact Acceleration Account [ES/M500392/1] and the Alliance Manchester Business School (AMBS) Lord Alliance strategic research investment fund [LA-SRIF AA14179].

Open Access This article is distributed under the terms of the Creative Commons Attribution 4.0 International License (http://creativecommons.org/licenses/by/4.0/), which permits unrestricted use, distribution, and reproduction in any medium, provided you give appropriate credit to the original author(s) and the source, provide a link to the Creative Commons license, and indicate if changes were made.

\section{References}

Ahmed, M. (2011). An economic crisis state? In M. Lodhi (Ed.), Pakistan: Beyond the “crisis state” (pp. 169-200). London: Hurst.

Alfalah. (2015). Rising it exports. Karachi: Dawn. https://www.dawn.com/news/1219909. Retrieved 12 Dec 2018.

Allen, J. (2003). Lost geographies of power. Malden: Blackwell. 
Alvesson, M., \& Kärreman, D. (2007). Constructing mystery: Empirical matters in theory development. Academy of Management Review, 32(4), 1265-1281.

Awate, S., Larsen, M. M., \& Mudambi, R. (2012). EMNE catch-up strategies in the wind turbine industry: Is there a trade-off between output and innovation capabilities? Global Strategy Journal, 2(3), 205-223.

Beugelsdijk, S., \& Mudambi, R. (2013). MNEs as border-crossing multi-location enterprises: The role of discontinuities in geographic space. Journal of International Business Studies, 44(5), 413-426.

Bilgili, T. V., Kedia, B. L., \& Bilgili, H. (2016). Exploring the influence of resource environments on absorptive capacity development: The case of emerging market firms. Journal of World Business, 51(5), 700-712.

Bokhari, F. (2000). Survey-IT Indian sub-continent: A panacea for economic woes. Financial Times. London: Nikkei, p. 4.

Brück, T., Naudé, W., \& Verwimp, P. (2011). Small business, entrepreneurship and violent conflict in developing countries. Journal of Small Business and Entrepreneurship, 24(2), 161-178.

Buckley, P. J., Craig, T. D., \& Mudambi, R. (2018). Time to learn? Assignment duration in global value chain organization. Journal of Business Research. https://doi.org/10.1016/j.jbusres.2018.01.011.

Buckley, P. J., \& Strange, R. (2015). The governance of the global factory: Location and control of world economic activity. Academy of Management Perspectives, 29(2), 237-249.

Cano-Kollmann, M., Cantwell, J., Hannigan, T. J., Mudambi, R., \& Song, J. (2016). Knowledge connectivity: An agenda for innovation research in international business. Journal of International Business Studies, 47(3), 255-262.

Carroll, C. (2002). Pakistan pulls plug on valley tech office. Mercury News. San Jose: Bay Area News Group.

Choksy, U. S. (2015). Upgrading and power relations in global value chains: Case study of an offshoring service provider in the software industry. In R. Van Tulder, A. Verbeke, \& R. Drogendijk (Eds.), The future of global organizing (Vol. 10, pp. 437-465). Bingley: Emerald Group Publishing.

Choksy, U. S., Sinkovics, N., \& Sinkovics, R. R. (2017). Exploring the relationship between upgrading and capturing profits from GVC participation for disadvantaged suppliers in developing countries. Canadian Journal of Administrative Sciences, 34(4), 356-386.

Christophe, J. (2015). The Pakistan paradox: Instability and resilience. Oxford: Oxford University Press.

Cook, G., Johns, J., McDonald, F., Beaverstock, J., \& Pandit, N. (2018). The routledge companion to the geography of international business. London: Routledge.

Currie, W. L., \& Seltsikas, P. (2001). Exploring the supply-side of it outsourcing: Evaluating the emerging role of application service providers. European Journal of Information Systems, 10(3), $123-134$.

Czinkota, M. R., Knight, G., Liesch, P. W., \& Steen, J. (2010). Terrorism and international business: A research agenda. Journal of International Business Studies, 41(5), 826-843.

Dai, L., Eden, L., \& Beamish, P. W. (2013). Place, space, and geographical exposure: Foreign subsidiary survival in conflict zones. Journal of International Business Studies, 44(6), 554-578.

Dalesio, E. P. (2001). Companies head offshore for cheaper programming brainpower. Associated Press Archive. London: Associated Press.

Doh, J. P., Bunyaratavej, K., \& Hahn, E. D. (2009). Separable but not equal: The location determinants of discrete services offshoring activities. Journal of International Business Studies, 40(6), 926-943.

Duan, J., \& Zhu, Q. (2011). A requirement-driven approach to enterprise application evolution. ICIC Express Letters, Part B: Applications, 2(2), 313-318.

Duan, J., Zhu, Q., \& Guan, Z. (2010). A requirement-driven approach to enterprise application development. In F. L. Wang, Z. Gong, X. Luo, \& J. Lei (Eds.), Web information systems and mining. WISM 2010. Lecture Notes in Computer Science (Vol. 6318, pp. 295-302). Berlin: Springer.

Eisenhardt, K. M., \& Graebner, M. E. (2007). Theory building from cases: Opportunities and challenges. Academy of Management Journal, 50(1), 25-32.

Felin, T., Foss, N. J., Heimeriks, K. H., \& Madsen, T. L. (2012). Microfoundations of routines and capabilities: Individuals, processes, and structure. Journal of Management Studies, 49(8), 1351-1374.

Felin, T., Foss, N. J., \& Ployhart, R. E. (2015). The microfoundations movement in strategy and organization theory. Academy of Management Annals, 9(1), 575-632.

Foss, N. (2009). Alternative research strategies in the knowledge movement: From macro bias to microfoundations and multi-level explanation. European Management Review, 6(1), 16-28.

Gereffi, G., \& Fernandez-Stark, K. (2016). Global value chain analysis: A primer (2nd ed.). Durham: Duke CGGC (Center on Globalization, Governance and Competitiveness). 
Gereffi, G., Humphrey, J., \& Sturgeon, T. (2005). The governance of global value chains. Review of International Political Economy, 12(1), 78-104.

Hammond, K. R. (1966). Probabilistic functionalism: Egon Brunswick's integration of the history, theory, and method of psychology. In K. R. Hammond (Ed.), The psychology of egon brunswik (pp. 15-80). New York: Holt, Rinehart and Winston.

Hannigan, T. J., \& Mudambi, R. (2015). Local R\&D won't help you go global. Harvard Business Review online. https://hbr.org/2015/06/local-rt-help-you-go-global. Retrieved 11 Nov 2018.

Hassan, S. Z. (2000). Software industry evolution in a developing country: An in depth study. In R. H. Sprague (Ed.), Proceedings of the 33rd annual Hawaii international conference on system sciences (Vol. 2, pp. 1-10). Maui: IEEE Computer Society.

He, W., \& Xu, L. D. (2014). Integration of distributed enterprise applications: A survey. IEEE Transactions on Industrial Informatics, 10(1), 35-42.

Hess, M. (2008). Governance, value chains and networks: An afterword. Economy and Society, 37(3), $452-459$.

Hiatt, S. R., \& Sine, W. D. (2014). Clear and present danger: Planning and new venture survival amid political and civil violence. Strategic Management Journal, 35(5), 773-785.

Holzer, A., \& Ondrus, J. (2009). Trends in mobile application development. In C. Hesselman \& C. Giannelli (Eds.), Mobile wireless middleware, operating systems, and applications-Workshops (pp. 55-64). Berlin: Springer.

Holzer, A., \& Ondrus, J. (2011). Mobile application market: A developer's perspective. Telematics and Informatics, 28(1), 22-31.

Hoque, S. F., Sinkovics, N., \& Sinkovics, R. R. (2016). Supplier strategies to compensate for knowledge asymmetries in buyer-supplier relationships: Implications for economic upgrading. European Journal of International Management, 10(3), 254-283.

Hoskisson, R. E., Wright, M., Filatotchev, I., \& Peng, M. W. (2013). Emerging multinationals from midrange economies: The influence of institutions and factor markets. Journal of Management Studies, 50(7), 1295-1321.

Hussain, Z. (2011). Battling militancy. In M. Lodhi (Ed.), Pakistan: Beyond the “crisis state” (pp. 131148). London: Hurst.

Jain, D. M., \& Khurana, R. (2016). A framework to study vendors' contribution in a client vendor relationship in information technology service outsourcing in India. Benchmarking: An International Journal, 23(2), 338-358.

Jamal, N. (2003). Pakistan's software exports decline. Karachi: Dawn.

Jensen, P. D. Ø., \& Petersen, B. (2013). Global sourcing of services: Risk, process, and collaborative architecture. Global Strategy Journal, 3(1), 67-87.

Jones, A., \& Murphy, J. T. (2010). Practice and economic geography. Geography. Compass, 4(4), 303-319.

Jones, A., \& Murphy, J. T. (2011). Theorizing practice in economic geography: Foundations, challenges, and possibilities. Progress in Human Geography, 35(3), 366-392.

Kawakami, M., \& Sturgeon, T. J. (2011). The dynamics of local learning in global value chains: Experiences from East Asia. Houndmills: Palgrave Macmillan.

Kenney, M., \& Pon, B. (2011). Structuring the smartphone industry: Is the mobile internet os platform the key? Journal of Industry, Competition and Trade, 11(3), 239-261.

Kessler, M. (2001). 'Brain drain' shifts into reverse. USA TODAY, p. 3B.

Khan, A. (2001). Software industry in crisis. Karachi: Dawn.

Khan, A. (2011). Pakistan's it exports set to witness tremendous growth. Business Recorder. Karachi: Business Recorder Group.

Khan, M. H. (2014). Aid and governance in vulnerable states: Bangladesh and Pakistan since 1971. Annals of the American Academy of Political and Social Science, 656(1), 59-78.

Khan, Z., \& Lew, Y. K. (2018). Post-entry survival of developing economy international new ventures: A dynamic capability perspective. International Business Review, 27(1), 149-160.

Khozem, M. (2001). Deregulation will aid it ambitions. Financial Times (p. 3). London: Nikkei Inc.

King, N. (2012). Doing template analysis. In G. Symon \& C. Cassell (Eds.), Qualitative organizational research: Core methods and current challenges (pp. 426-450). London: Sage Publications.

Kumaraswamy, A., Mudambi, R., Saranga, H., \& Tripathy, A. (2012). Catch-up strategies in the Indian auto components industry: Domestic firms' responses to market liberalization. Journal of International Business Studies, 43(4), 368-395. 
Lee, J., \& Gereffi, G. (2015). Global value chains, rising power firms and economic and social upgrading. Critical Perspectives on International Business, 11(3-4), 319-339.

Lee, K., Park, T. Y., \& Krishnan, R. T. (2014). Catching-up or leapfrogging in the Indian it service sector: Windows of opportunity, path-creating, and moving up the value chain. Development Policy Review, 32(4), 495-518.

Lema, R. (2010). Adoption of open business models in the west and innovation in India's software industry. IDS Research Reports, $2010(62), 1-144$.

Lema, R. (2011). Outsourcing and the rise of innovative software services in Bangalore. Innovation and Development, 1(1), 164.

Lema, R. (2015). Problem-framing in new innovation spaces: Insights from software outsourcing. In M. McKelvey \& S. Bagchi-Sen (Eds.), Innovation spaces in Asia: Entrepreneurs, multinational enterprises and policy (pp. 279-300). Cheltenham: Edward Elgar.

Lema, R., Quadros, R., \& Schmitz, H. (2015). Reorganising global value chains and building innovation capabilities in Brazil and India. Research Policy, 44(7), 1376-1386.

Lodhi, M. (2011a). Beyond the crisis state. In M. Lodhi (Ed.), Pakistan: Beyond the "crisis state" (pp. 45-78). London: Hurst.

Lodhi, M. (Ed.). (2011b). Pakistan: Beyond the "crisis state”. London: Hurst.

Lopez-Calix, J., \& Touqeer, I. (2013). Revisiting the constraints to Pakistan's growth. Policy Paper Series on Pakistan. Washington: World Bank.

Lorenzen, M., \& Mudambi, R. (2010). Bangalore vs. Bollywood: Connectivity and catch-up in emerging market economies. AIB Insights, 10(1), 7-11.

Manning, S. (2014). Mitigate, tolerate or relocate? Offshoring challenges, strategic imperatives and resource constraints. Journal of World Business, 49(4), 522-535.

Manning, S., Larsen, M. M., \& Bharati, P. (2015). Global delivery models: The role of talent, speed and time zones in the global outsourcing industry. Journal of International Business Studies, 46(7), 850-877.

McDermott, G., Mudambi, R., \& Parente, R. (2013). Strategic modularity and the architecture of multinational firm. Global Strategy Journal, 3(1), 1-7.

Mudambi, R. (2008). Location, control and innovation in knowledge-intensive industries. Journal of Economic Geography, 8(5), 699-725.

Murphy, J. T. (2003). Social space and industrial development in East Africa: Deconstructing the logics of industry networks in Mwanza. Tanzania. Journal of Economic Geography, 3(2), 173-198.

Pezderka, N., \& Sinkovics, R. R. (2011). A conceptualization of e-risk perceptions and implications for small firm active online internationalization. International Business Review, 20(4), 409-422.

Pfeffer, J., \& Salancik, G. R. (1978). The external control of organizations: A resource dependence perspective. New York: Harper and Row.

Plank, L., \& Staritz, C. (2015). Global competition, institutional context and regional production networks: Up- and downgrading experiences in Romania's apparel industry. Cambridge Journal of Regions, Economy and Society, 8(3), 421-438.

Ponte, S., \& Sturgeon, T. (2014). Explaining governance in global value chains: A modular theory-building effort. Review of International Political Economy, 21(1), 195-223.

Ponte, S., Sturgeon, T. J., \& Dallas, M. (2019). Governance and power in global value chains. In S. Ponte, G. Gereffi \& G. Raj-Reichert (Eds.), The handbook of global value chains. Cheltenham: Edward Elgar. (forthcoming).

PSEB. (2010). Pakistan market it assessment. Islamabad: Pakistan Software Export Board. http://www. pseb.org.pk/images/study/pseb_it_market_review.pdf. Accessed 05 May 2012.

PSEB. (2012). Powering the world of infotaintment: A snapshot of Pakistan's mobile, gaming, and animation industry. Islamabad: Pakistan Software Export Board.

Richardson, C. (2011). Perception of export barriers in a high-tech sector in a less developed country: The case of ICT SMEs in Malaysia. The South East Asian Journal of Management, 5(2), 91-105.

Rousseva, R. (2008). Identifying technological capabilities with different degrees of coherence: The challenge to achieve high technological sophistication in latecomer software companies (based on the bulgarian case). Technological Forecasting and Social Change, 75(7), 1007-1031.

SBP. (2007). Exports of goods and services. Karachi: State Bank of Pakistan.

SBP. (2008). Exports of goods and services. Karachi: State Bank of Pakistan.

SBP. (2009). Exports of goods and services. Karachi: State Bank of Pakistan.

SBP. (2010). Exports of goods and services. Karachi: State Bank of Pakistan.

SBP. (2011). Exports of goods and services. Karachi: State Bank of Pakistan. 
Schotter, A., \& Beamish, P. W. (2013). The hassle factor: An explanation for managerial location shunning. Journal of International Business Studies, 44(5), 521-544.

Schotter, A. P. J., Mudambi, R., Doz, Y. L., \& Gaur, A. (2017). Boundary spanning in global organizations. Journal of Management Studies, 54(4), 403-421.

Sinkovics, N. (2018). Pattern matching in qualitative analysis. In C. Cassell, A. Cunliffe, \& G. Grandy (Eds.), The sage handbook of qualitative business and management research methods (pp. 468485). Thousand Oaks: Sage Publications.

Sinkovics, N., Hoque, S. F., \& Sinkovics, R. R. (2018). Supplier strategies and routines for capability development: Implications for upgrading. Journal of International Management, 24(4), 348-368.

Sinkovics, N., \& Sinkovics, R. R. (2019). International business and global value chains. In S. Ponte, G. Gereffi \& G. Raj-Reichert (Eds.), The handbook of global value chains. Cheltenham: Edward Elgar. (forthcoming).

Sinkovics, N., Sinkovics, R. R., Hoque, S., \& Czaban, L. (2015). A reconceptualization of social value creation as social constraint alleviation. Critical Perspectives on International Business, 11(3/4), 340-363.

Sinkovics, N., Sinkovics, R. R., \& Jean, R. J. B. (2013). The internet as an alternative path to internationalization? International Marketing Review, 30(2), 130-155.

Sinkovics, N., Sinkovics, R. R., \& Yamin, M. (2014). The role of social value creation in business model formulation at the bottom of the pyramid-Implications for MNEs? International Business Review, 23(4), 692-707.

Sinkovics, R. R., \& Alfoldi, E. A. (2012). Progressive focusing and trustworthiness in qualitative research: The enabling role of computer-assisted qualitative data analysis software (CAQDAS). Management International Review, 52(6), 817-845.

Sinkovics, R. R., Penz, E., \& Ghauri, P. N. (2008). Enhancing the trustworthiness of qualitative research in international business. Management International Review, 48(6), 689-714.

Sturgeon, T. J. (2009). From commodity chains to value chains: Interdisciplinary theory building in an age of globalization. In J. Bair (Ed.), Frontiers of commodity chain research (pp. 110-135). Stanford: Stanford University Press.

Thelen, S. T., Honeycutt, E. D., \& Murphy, T. P. (2010). Services offshoring: Does perceived service quality affect country-of-service origin preference? Managing Service Quality: An International Journal, 20(3), 196-212.

Tornroos, J.-A., Halinen, A., \& Medlin, C. J. (2017). Dimensions of space in business network research. Industrial Marketing Management, 61, 10-19.

Vitari, C., \& Ravarini, A. (2009). A longitudinal analysis of trajectory changes in the software industry: The case of the content management application segment. European Journal of Information Systems, 18(3), 249-263.

Voss, C., Tsikriktsis, N., \& Frohlich, M. (2002). Case research in operations management. International Journal of Operations and Production Management, 22(2), 195-219.

Wu, J., \& Chen, X. (2014). Home country institutional environments and foreign expansion of emerging market firms. International Business Review, 23(5), 862-872.

Xudong, S., Xueping, W., \& Xiaobing, L. (2008). Research on enterprise application integration architecture and development approach. In Proceedings of 2 nd 2008 international symposium on intelligent information technology application workshop, IITA 2008 workshop (pp. 215-218). https://doi. org/10.1109/IITA.Workshops.2008.243.

Yamin, M., \& Sinkovics, R. R. (2006). Online internationalisation, psychic distance reduction and the virtuality trap. International Business Review, 15(4), 339-360.

Yousaf, S., \& Li, H. (2015). Social identity, collective self esteem and country reputation: The case of Pakistan. Journal of Product and Brand Management, 24(4), 399-411.

Yusuf, M. (2013). The intersection of development, politics, and security. In A. M. Weiss \& S. G. Khattak (Eds.), Development challenges confronting Pakistan (pp. 239-266). London: Kumarian Press.

Zaidi, S. A. (2015). Issues in Pakistan's economy: A political economy perspective. Karachi: Oxford University Press. 